\title{
Connecting Reproductive Rights, Democracy, and the Rule of Law: Lessons from Poland in Times of COVID-19
}

\author{
Atina Krajewska \\ Birmingham Law School, University of Birmingham, Birmingham, United Kingdom \\ Corresponding author: A.Krajewska.1@bham.ac.uk
}

(Received 11 June 2021; accepted 22 June 2021)

\begin{abstract}
This article examines the relationship between reproductive rights, democracy, and the rule of law in transitional societies. As a case study, it examines the development of abortion law in Poland. The article makes three primary claims. First, it argues that the relationship between reproductive rights and the rule of law in Poland came clearly into view through the abortion judgment K 1/20, handed down by the Constitutional Tribunal in the middle of the COVID-19 pandemic. The judgment and the context in which it was issued and published are interpreted as reflections of deep-lying processes and problems in Polish society. Consequently, second, the article argues that analysis of the history of reproductive rights in recent decades in Poland reveals weak institutionalization of the rule of law. This is manifest in the ways in which different professional groups, especially doctors and lawyers, have addressed questions regarding abortion law. Therefore, third, the article argues that any assessment of the rule of law should take into account how powerful professional actors and organizations interact with the law. The Polish case study shows that reproductive rights should be seen as important parts of a "litmus test," which we can use to examine the efficacy of democratic transitions and the quality of the democracies in which such transitions result.
\end{abstract}

Keywords: Abortion law; reproductive rights; the rule of law; Poland; democratization; transitional society; democratic breakdown; constitutional backsliding; Covid-19

\section{A. Introduction}

Across the world, many governments responded to the COVID-19 pandemic by substantially extending their executive emergency powers. ${ }^{1}$ This raised concerns about the weakening of existing systems of checks and balances in national constitutions, and it was seen as a threat

Dr Atina Krajewska holds degrees from the University of Wroclaw, Poland, and Humboldt University in Berlin, Germany, and has worked at UK universities since 2008. Her work brings together insights from socio-legal studies of healthcare, transnational legal theory, the sociology of law, and the sociology of professions. Within these general parameters, she uses sexual and reproductive rights as a case study to examine broader sociological and legal phenomena constituting health law. In the past, she acted as an ad hoc adviser to the Polish government and UK regulators and she has been a recipient of funding from the DAAD, the British Academy, the Leverhulme Trust, and the ESRC. She collaborates with a number of civil society organisations concerned with the improvement of sexual and reproductive rights in different countries across the world.

She would like to thank Patrycja Dąbrowska-Kłosińska, Fiona de Londras, Michał Kazek, and Chris Thornhill for their insightful comments and suggestions, which helped refine the argument presented in this article. She would also like to thank Alan Greene and Michał Gajewski for their suggestions concerning the "state of emergency."

${ }^{1}$ Although some scholars have claimed "executive underreach" in some cases. See David E. Pozen \& Kim Lane Scheppele, Executive Underreach, in Pandemics and Otherwise, 114 AM. J. INT'L L. 608 (2020).

(C) The Author(s) 2021. Published by Cambridge University Press on behalf of the German Law Journal. This is an Open Access article, distributed under the terms of the Creative Commons Attribution licence (http://creativecommons.org/licenses/by/4.0/), which permits unrestricted re-use, distribution, and reproduction in any medium, provided the original work is properly cited. 
to the rule of law. ${ }^{2}$ In some countries, the outbreak of COVID-19 coincided with the wider crisis or weakening of constitutional democracy, typically described as "democratic decay," "authoritarian reversion,"4 "stealth authoritarianism," "anti-constitutional populist backsliding," "constitutional breakdown," and "rule of law backsliding." Pech and Sheppele define the latter as the process through which elected public authorities deliberately implement governmental blueprints that aim to systematically weaken, annihilate, or capture internal checks on power in order to dismantle the liberal democratic state and entrench the long-term rule of the dominant party. ${ }^{7}$ Such processes-witnessed in countries which relatively recently transitioned to democracy such as Brazil, Hungary, Poland, or in longer-standing democracies such as the UK or the USA-have received considerable attention in the literature. The impact of the COVID-19 pandemic on these processes is a problem that requires urgent attention, especially as governments impose unprecedented restrictions on individual rights and freedoms. ${ }^{8}$ Most controversies in this context have focused on restrictions on freedom of movement and the freedom of economic activity. However, there are other rights and equally pressing questions to consider.

Notably, reproductive rights constitute a category of rights of high significance, both intrinsically and in terms of their broader socio-political implications. Historically, of course, feminist scholars have challenged the public versus private divide in law and politics. They have demonstrated that reproductive rights, often considered by legal interpreters as belonging to the sphere of private life, are inherently political and public. In particular, they have highlighted the connections between reproductive rights, citizenship, and the state. ${ }^{9}$ Such insights acquire particular validity in the context of late-transitional states such as Poland. In fact, like more straightforwardly political rights, we can see that reproductive rights are enmeshed in the fabric of democracy as a whole, often forming de facto preconditions for democracy. Such rights encapsulate one of the most fundamental and intimate aspects of personal sovereignty. As such, experiences related to their realization have a powerful influence, both direct and indirect, on the rule of law and democracy.

This Article takes as a starting point for the discussion of the judgment issued by the Polish Constitutional Tribunal (CT) that resulted in a de facto ban on abortion services in Poland. ${ }^{10}$ The

\footnotetext{
${ }^{2}$ Alan Greene, Emergency Powers in a Time of Pandemic (2020); Gábor Halmai \& Kim Lane Scheppele, Don't Be Fooled by Autocrats!: Why Hungary's Emergency Violates Rule of Law, VerfassungBlog (Apr. 22, 2020), https:// verfassungsblog.de/dont-be-fooled-by-autocrats/.[All internet sources accessed on 8 June 2021].

${ }^{3}$ Tom G. Daly, Democratic Decay: Conceptualising an Emerging Research Field, 11 Hague J. Rule L. 9 (2019); Tom G Daly, Enough Complacency: Fighting Democratic Decay in 2017, InT'L J. Const. L. BLOG (Jan. 11, 2017), http://www.iconnectblog. com/2017/01/enough-complacency-fighting-democratic-decay-in-2017-i-connect-column/.

${ }^{4}$ Aziz Huq \& Tom Ginsburg, How to Lose a Constitutional Democracy, 65 UCLA L. Rev. 78 (2018).

${ }^{5}$ Ozan Varol, Stealth Authoritarianism, 100 IowA L. ReV. 1673 (2015).

${ }^{6}$ WojCiech SAdurski, Poland's Constitutional Breakdown (2019).

${ }^{7}$ Laurent Pech \& Kim Lane Scheppele, Illiberalism Within: Rule of Law Backsliding in the EU, 19 CAMBRIDGE Y.B. EUR. LEGAL STUd. 3, 10 (2017).

${ }^{8}$ Edward Kirton-Darling, Helen Carr \& Tracey Varnava, Legislating for a Pandemic: Exposing the Stateless State, 47 J. L. Soc'y S302 (2020); Lisa Forman \& Jillian Clare Kohler, Global Health and Human Rights in the Time of COVID-19: Response, Restrictions, and Legitimacy, 19 J. Hum. RTs. 547 (2020); George Duke, Sovereignty's Rationale: Afterword to the Foreword by Neil Walker, 19 InT'L J. Const. L. 13 (2020); Michelle Roccato, Nicoletta Cavazza, Pasquale Colloca \& Silvia Russo, A Democratic Emergency After a Health Emergency? Exposure to COVID-19, Perceived Economic Threat and Support for Anti-Democratic Political Systems, 10 Soc. SCI. Q. 2193 (2020).

${ }^{9}$ Rosalind P. Petchesky, Abortion and Woman's Choice: The State, Sexuality, and Reproductive Freedom (1997); Joanna Mishtal, The Politics of Morality: The Church, the State and Reproductive Rights in Postsocialist Poland (2015); Kristin Luker, Abortion And the Politics of Motherhood (1984); Małgorzata Fuszara, Citizenship, Representation and Gender, 172 Polish Socio. Rev. 367 (2010); Ruth Lister, Citizenship: Feminist Perspectives (1997); Kenneth Plummer, Intimate Citizenship: Private Decisions and Public Dialogues (2003); Beyond Citizenship? Feminism and the Transformation of Belonging (Sasha Roseniel ed., 2013); Liiri Oja \& Alicia Ely Yamin, "Woman" in the European Human Rights System: How is the Reproductive Rights Jurisprudence of the European Court of Human Rights Constructing Narratives of Women's Citizenship?, 32 COLUM. J. GENDER \& L. 62 (2016).

${ }^{10}$ Wyrok [Judgment] of CT [Constitutional Tribunal] Oct. 20, 2020, K 1/20 (Dz. U. 2021.175) (Pol.), https://www.prawo.pl/ akty/dz-u-2021-175,19075113.html.
} 
Article argues that the judgment K 1/20 issued on October 22, 2020 - at the start of the second wave of the COVID-19 pandemic in Poland-has made evident the co-constitutive relationship between reproductive rights, the rule of law, and democracy. This juxtaposition is often ignored by legal literature concerning the rule of law. The regulation of abortion and other reproductive rights, although acknowledged by some scholars as a constitutional problem, ${ }^{11}$ is usually seen as a phenomenon that is separate from and peripheral to the problem of the rule of law, and it is rarely considered relevant to the functioning of democracy in contemporary societies. Most authors studying "constitutional breakdown" have omitted to show full regard for the intensifying retrenchment in the sphere of reproductive rights that has taken place in many of the countries experiencing a constitutional crisis. For example, Sadurski, writing about the protests against the restrictions of abortion law in Poland, described these demonstrations as episodic "single-issue protests." 12 In particular, academic literature on the importance of protection for fundamental rights in transitional and post-transitional societies typically emphasizes the significance of rights with obvious political or perhaps socio-economic implications, but often fails to include reproductive rights in these discussions. Both academics and the international community that heralded the successful processes of democratic transition in Central and Eastern European states seemed to accept that successful transition to a constitutional democracy is possible without due regard for the protection and implementation of sexual and reproductive rights.

The Article challenges such assumptions. It takes the abortion judgment K 1/20 as a focal point to argue that the level of protection of reproductive rights should be seen as an integral part of a "litmus test" for successful transitions and the functioning of constitutional democracies more broadly. First, the Article examines the way in which the COVID-19 pandemic created a unique opportunity for the CT-already controlled by the ruling Law and Justice party-to issue the abortion judgment restricting already draconian abortion law in Poland. The Article demonstrates how the outbreak of COVID-19 led to the adoption of special regulations that gave to law-enforcement agencies emergency powers that brought serious curtailment of civil and political freedoms. These powers were later used to contain the protests that erupted after the announcement of the abortion judgment. At the same time, the COVID-19 pandemic cannot be seen as the root cause of the abortion judgment, but as a trigger that has accelerated and intensified the "constitutional breakdown" experienced by Polish society in recent years. The judgment and its aftermath revealed the full scale and reinforced existing trends and patterns in this breakdown. Therefore, second, the Article subsequently explains how important evidence of the constitutional crisis can be found in the reasoning of the judgment and the broader context in which it was issued. In particular, the Article discusses ways in which the judgment K 1/20 reflects the consequences of selective judicial appointments to the CT-such as "court-packing" - conducted by the ruling Law and Justice party. As such, the Article demonstrates how the recent retrenchment of reproductive rights is closely associated with the broader "anti-constitutional populist backsliding."

The Article argues that this trend is by no means unique to Poland and that, in other countries, alliances between anti-abortion and anti-constitutional factions can also be observed. The Article accepts commonly proposed arguments that the emergence of populist conservative governments often leads to the rapid weakening of reproductive rights protection. However, it goes much further than this. Namely, it claims that the reverse is possible: the retrenchment of reproductive rights may often indicate problems with the rule of law. Although the relationship between reproductive rights and the rule of law is not one of straightforward causation but rather of complex correlation, it exists and is an important indication of the quality of democratic government. Consequently, third, the Article examines the persistent disregard for reproductive rights in Poland, demonstrating its

\footnotetext{
${ }^{11}$ Donald. P. Kommers, Abortion and Constitution: United States and West Germany, 25 AM. J. ComP. L. 255 (1977); Reva B. Siegel, The Constitutionalization of Abortion, in AbOrTION LAW IN Transnational Perspective 13 (Rebecca J. Cook, Joanna N. Erdman \& Bernard M. Dickens eds., 2014); Paola Bergallo \& Agustina Ramón Michel, Constitutional Developments in Latin American Abortion Law, 135 INT'L J. GYNECOL. \& OBSTET. 228 (2016).

${ }^{12}$ SADURSKI, supra note 6 , at 9.
} 
consequences for the rule of law. This analysis goes beyond a simple acknowledgment that violations of reproductive rights - human rights - constitute inherent violations of the rule of law. The Polish case study suggests that disregard for reproductive rights may both reflect and, in turn, intensify weaknesses in democratic culture and contribute to the broader erosion of legitimate institutions. The analysis demonstrates how, long before 2015, the implementation of reproductive rights in Poland indicated that the rule of law was weakly institutionalized. ${ }^{13}$ In this respect, the Article emphasizes the role of healthcare professionals in the consolidation of democratic structures. Consequently, it argues for the inclusion of this professional group, alongside the legal profession, to assess the levels of entrenchment of the rule of law. As a result, the Article makes clear that adequate protection of reproductive rights cannot be viewed as a marginal aspect of democracy and that such rights are an essential element of the legal fabric of a democratic society.

\section{B. Abortion in Times of COVID-19: Immediate Factors Influencing the Recent Development of Reproductive Rights}

\section{The Judgment K $1 / 20$ as Part of a Wider Trend}

There is much evidence that the outbreak of the COVID-19 pandemic exacerbated existing legal, socio-economic, and geographical barriers to accessing reproductive health services. It also created new ones. ${ }^{14}$ Many governments remained silent on how the health system should address the problem of access to abortion services during the pandemic. ${ }^{15}$ This inactivity created new barriers as resources were reallocated, and providers faced challenges linked to illness and quarantines. ${ }^{16}$ Furthermore, the outbreak of COVID-19 has arguably intensified trends that were visible before the pandemic. On the one hand, in countries like France, Great Britain, Ireland, South Africa, and parts of the USA, abortion regulation was specifically relaxed in response to the challenges posed by the pandemic, ${ }^{17}$ and in Thailand and South Korea, apex courts also moved the law towards broader access to reproductive health services. ${ }^{18}$ On the other hand, in other countries, the

\footnotetext{
${ }^{13}$ In this respect, the article challenges the claims expressed by Aleksandra Gliszczyńska-Grabias \& Wojciech Sadurski in The Judgment That Wasn't (But Which Nearly Brought Poland to a Standstill): 'Judgment' of the Polish Constitutional Tribunal of 22 October 2020, K 1/20, 17 EUR. CONST. L. REv. 130 (2021).

${ }^{14}$ Julia Hussein, COVID-19: What Implications for Sexual and Reproductive Health and Rights Globally?, 28 SEXUAL \& REPROD. HeAlth Matters 1 (2020); Kelli Stidham Hall, Goleen Samari, Samantha Garbers, Sarah E. Casey, Dazon Dixon Diallo, Miriam Orcutt, Rachel T. Moresky, Michaela Elvira Martinez \& Terry McGovern, Comment, Centering Sexual and Reproductive Health and Justice in the Global COVID-19 Response, 395 LANCET 1175 (2020); Clare Wenham, Julia Smith \& Rosemary Morgan, COVID-19: The Gendered Impacts of the Outbreak, 395 LANCET 846 (2020); Zara Ahmed \& Adam Sonfield, The COVID-19 Outbreak: Potential Fallout for Sexual and Reproductive Health and Rights, GuTTMACHER Inst. (March 11, 2020), https:// www.guttmacher.org/article/2020/03/covid-19-outbreak-potential-fallout-sexual-and-reproductive-health-and-rights.

${ }^{15} \mathrm{~A}$ large survey of regulatory changes in forty-six European states showed that, "none of the surveyed countries/regions expanded the legal gestational age limit for abortions ... and none of the 12 surveyed countries/regions requiring mandatory waiting periods officially lifted this regulation.” See Caroline Moreau, Mridula Shankar, Anna Glasier, Sharon Cameron \& Kristina Gemzell-Danielsson, Abortion Regulation in Europe in the Era of COVID-19: A Spectrum of Policy Responses, BMJ SeXUAL \& RePROD. HeAlth (Oct. 22, 2020), https://srh.bmj.com/content/early/2021/02/22/bmjsrh-2020-200724.

${ }^{16}$ Jaime Todd-Gher \& Payal K. Shah, Abortion in the Context of COVID-19: A Human Rights Imperative, 28 SEXUAL \& Reprod. Health Matters 1 (2020).

${ }^{17}$ The extent of liberalization remains to be seen as some governments stressed that the changes are introduced only for a specific period of time and will be reviewed once the pandemic comes under control. See Elizabeth Chloe Romanis, Jordan A. Parsons \& Nathan Hodson, COVID-19 and Reproductive Justice in Great Britain and the United States: Ensuring Access to Abortion Care During a Global Pandemic, 7 J. L. \& BIOSCIENCES 1 (2020).

${ }^{18}$ The Constitutional Court of Thailand ruled that the penal code provisions criminalizing abortion were partially unconstitutional and ordered the legislature to amend the code. See Miss Srisamai Cheuachat v. Respondent, Ruling, No. 4/2563, The Constitutional Court of the Kingdom of Thailand (Feb. 19, 2020), https://perma.cc/3D7Z-54CZ. Consequently, on January 25 , 2021, the National Assembly of Thailand relaxed currently restrictive regulations on abortion by decriminalizing the termination of pregnancy during the first twelve weeks. See Act Amending the Criminal Code (No. 28), B.E., 2554, sec. 2, http:// www.ratchakitcha.soc.go.th/DATA/PDF/2564/A/010/T_0001.PDF; See Thailand: Abortion in First Trimester Legalized, LIBR. CONG. (Mar. 1, 2021), https://www.loc.gov/law/foreign-news/article/thailand-abortion-in-first-trimester-legalized/. In South
} 
pandemic has been instrumentalized to implement earlier long-term policies and political agendas aimed at reproductive rights restrictions. For instance, in Brazil, the Federal Board of Medicine and the Regional Boards of Medicine-professional regulatory bodies-used COVID-19 to issue professional guidelines, which effectively restricted access to abortion services. ${ }^{19}$ In the USA, states like Alabama, Arkansas, Iowa, Louisiana, Ohio, Tennessee, Texas, and West Virginia have all witnessed intermittent bans on abortion as ultra-conservative anti-abortion politicians categorized abortion services as non-essential, banning abortion clinics from performing what they defined as elective surgical procedures. ${ }^{20} \mathrm{~A}$ temporary suspension for similar reasons took place in Hungary, where the government is pursuing an increasingly conservative agenda in the field of reproductive rights. ${ }^{21}$ In most of these countries, the courts either blocked such changes or restored the pre-COVID-19 legal or regulatory situation.

It could be argued that Poland falls within wider patterns of governmental behavior in times of Coronavirus. While abortion services were not explicitly prohibited or deprioritized during the pandemic, the Director of the National Health Fund (NFZ) issued guidelines calling for a case-by-case assessment of healthcare services, which could be postponed. ${ }^{22}$ This meant that many hospitals practically stopped providing abortion services. ${ }^{23}$ Furthermore, as the overwhelming majority of abortions in Poland occurs unofficially, ${ }^{24}$ restrictions on freedom of movement, including international travel bans, had a particularly striking effect on the availability of abortion in comparison to other states in Europe. ${ }^{25}$ However, the Polish government decided to restrict access to abortion services even further. It seized the opportunity created by COVID-19 to accelerate its ultra-conservative anti-abortion policies that had been attempted many times before. ${ }^{26}$ As early as April 2020, it attempted to rush through Parliament a legislative proposal, which, if adopted, would have banned all abortions on the ground of fatal fetal anomaly. ${ }^{27}$ As the attempt was unsuccessful, the government changed its tactics. It used the CT to introduce the same change

Korea, abortion became decriminalized on January 1, 2021, when the provisions of Act No. 293, the Criminal Act, that criminalized abortion became invalid. Criminal Act, Act No. 293, Sept. 18, 1953, arts. 269-270, amended by Act No. 5057, Dec. 29, 1995, https://perma.cc/3D7Z-54CZ. See South Korea: Abortion Criminalized Since January 1, 2021, LIBR. CoNG. (Mar. 18, 2021), https://www.loc.gov/law/foreign-news/article/south-korea-abortion-decriminalized-since-january-1-2021/.

${ }^{19}$ Juliana Cesario Alvim Gomes \& Corina Helena Figueira Mendes, Confidentiality and Treatment Refusal: Conservative Shifts on Reproductive Rights by Brazilian Medical Boards, 152 INT'L. J. GYNECOL. \& OBSTET. 459 (2021).

${ }^{20}$ See Wendy K. Mariner, The Influence of Contagious Disease Emergencies on Judicial Review in the United States, GERMAN L. J. (forthcoming 2021). See also Jessica Glanza, States Use Coronavirus to Ban Abortions, Leaving Women Desperate: "You Can't Pause a Pregnancy", The GuARDiAn (Apr. 30, 2020), https://www.theguardian.com/world/2020/apr/30/us-states-banabortions-coronavirus-leave-women-desperate; Alan Smith, Texas, Ohio Order Clinics to Halt Abortion Procedures Amid Coronavirus, NBCNEws.com (Mar. 23, 2020), https://www.nbcnews.com/politics/politics-news/texas-ohio-order-clinicshalt-abortion-procedures-amid-coronavirus-n1167201; Sami Sparber, In win for Planned Parenthood, U.S. Supreme Court Wipes Case Law Supporting Texas Pandemic Abortion Ban from the Books, TeXAS TRIB. (Jan. 25, 2021), https://www. texastribune.org/2021/01/25/supreme-court-texas-abortion-ban/.

${ }^{21}$ Todd-Gher \& Shah, supra note 16.

${ }^{22}$ Odpowiedź Minsterstwa Zdrowia ws. Dostępu do Zabiegów Przerwania Ciąży w Czasie Epidemii [Response of the Ministry of Health Regarding Access to Abortion During an Epidemic], Ministry HeAlth (Apr. 4, 2020), https://federa.org.pl/wpcontent/uploads/2020/11/0164.26_inf.publ_dostep-do-zabiegow-przerwania-ciazy-w-czasie-epidemii_Federacja-na-rzecz-

Kobiet-i-Planowania-Rodziny-1.pdf.

${ }^{23}$ Todd-Gher \& Shah, supra note 16.

${ }^{24}$ Legal regulation and the stigmatization of abortion have forced women to seek reproductive healthcare abroad or the underground. See Pauline Cullen \& Elżbieta Korolczuk, Challenging Abortion Stigma: Framing Abortion in Ireland and Poland, 27 Sexual \& Reprod. Health Matters 6 (2019).

${ }^{25}$ Jessica Bateman \& Marta Kasztelan, In Poland, Abortion Access Worsens Amid Pandemic, Foreign PoL’y (Jan. 5, 2020), https://foreignpolicy.com/2020/05/01/poland-abortion-access-worsens-coronavirus-pandemic/.

${ }^{26}$ Julia Kubisa \& Katarzyna Rakowska, Was it a Strike? Notes on the Polish Women's Strike and the Strike of Parents of Persons with Disabilities', 30 PRAKTYKa TeORETyCzNa 15 (2018).

${ }^{27}$ Shaun Walker, Concerns over Polish Government Tightening Abortion Laws During Covid-19 Crisis, THE GuARDIAN, (Apr. 14, 2020), https://www.theguardian.com/world/2020/apr/14/concerns-over-polish-government-tightening-abortionlaws-during-covid-19-crisis. 
to the Act on Family Planning and the Protection of the Human Fetus 1993 (the 1993 Act ${ }^{28}$ via constitutional review. It is worth noting that the motion for constitutional review had been submitted to the CT as early as 2019 . The applicants, a group of 119 conservative MPs, argued that the provision of the 1993 Act, which had previously allowed women to access abortion on the grounds of fatal fetal abnormality, violated several constitutional provisions. ${ }^{29}$ The application was a convenient way to put the problem "on hold" in anticipation of more favorable conditions, which would allow changes in abortion law. Nevertheless, it took the Tribunal less than a year to issue its decision.

On October 22, 2020, the CT held unconstitutional Art 4a(1)-(2) of the 1993 Act. $^{30}$ The judgment came into force two months later, on January 27, 2021, upon its delayed publication in the Official Journal. ${ }^{31}$ Until then, Art $4 \mathrm{a}(1)$ of the Act 1993 allowed access to abortion where: The pregnant woman's life or health is at risk; medical examination suggests a high risk that the fetus would suffer severe and irreversible impairment or an incurable illness that could threaten its life; or the pregnancy is the result of an illegal act- rape or incest-up to the $12^{\text {th }}$ week of pregnancy.

According to Article $4 \mathrm{a}(2)$, abortion in the second case was permitted until the fetus reached viability and the third case up to the $12^{\text {th }}$ week of pregnancy. It is important to note that-unlike other jurisdictions-Polish criminal law only imposes sanctions on those who perform or assist in an abortion and not on persons having an abortion. As the Polish Criminal Code $1997^{32}$ uses the term "conceived child" instead of a fetus, the performance of an abortion falling outside the scope of the Act 1993 is considered an "offense against life and health". ${ }^{33}$ Under Article $152 \$ 1 \& 2$, "whoever, with consent of the woman, terminates her pregnancy in violation of the law," or "renders assistance to a pregnant woman in terminating her pregnancy in violation of the law or persuades her to do so" is a subject to imprisonment for up to three years. This provision is directed not only against healthcare professionals but against all persons assisting in the provision of unlawful abortions. Article $152 \S 3$ stipulates up to eight years of imprisonment for an abortion performed after the fetus has reached viability. Under Article 153, performing an abortion without the woman's consent carries a prison sentence of up to 8 years. In addition, Article 157 criminalizes the infliction of injuries to the body of the "conceived child." Consequently, the judgment $\mathrm{K} 1 / 20$ re-criminalized abortion on the ground of fatal fetal abnormality, placing such cases under the scope of Article $152 \S 1 \& 2$ as offenses against life and health. Given that in 2019, out of 1100 official abortions, 1074 were performed on the ground of fatal fetal anomaly, the judgment effectually amounts to a ban on abortions in Poland. ${ }^{34}$ It places the Polish abortion regime amongst the most restrictive in Europe, after Andorra, Malta, and San Marino, where abortions are prohibited on all grounds. ${ }^{35}$ It brings it close to the regulations in Liechtenstein, where abortion is only allowed in cases where a woman's life or health is at risk or the pregnancy is the result of sexual assault.

\footnotetext{
${ }^{28}$ Dz. U. 1993.17 .78 ze zm. (Pol.)., http://isap.sejm.gov.pl/isap.nsf/download.xsp/WDU19970880553/U/D19970553Lj.pdf.

${ }^{29}$ Wniosek o Stwierdzenie Niezgodności z Konstytucja Rzeczypospolitej Polskiej Aktu Normatywnego [Application for Declaration of Non-Compliance of a Normative Act with the Constitution of the Republic of Poland], CONST. TRIB. (Nov. 11, 2019), https://ipo.trybunal.gov.pl/ipo/view/sprawa.xhtml? \&pokaz=dokumenty\&sygnatura=K\%201/20.

${ }^{30} \mathrm{~K}$ 1/20 (Dz. U. 2021.175) (Pol.), https://trybunal.gov.pl/postepowanie-i-orzeczenia/wyroki/art/11300-planowanierodziny-ochrona-plodu-ludzkiego-i-warunki-dopuszczalnosci-przerywania-ciazy.

${ }^{31} I d$.

${ }^{32}$ Dz. U. 1997.88.553 ze zm (Pol.).

${ }^{33}$ Dz. U. 1997.88.553 ze zm. (Pol.).

${ }^{34}$ See Najczęstsze Przyczyny Aborcji ze Względu na Wady Płodu_Dane [The Most Common Causes of Abortion Due to Fetal Defects-Data], EvereTHNEws.PL (Oct. 23, 2020), https://everethnews.pl/newsy/najczestsze-przyczyny-aborcji-zewzgledu-na-wady-plodu-dane/.

${ }^{35}$ See The World's Abortion Laws, CTR. REPROD. RTs. (2021), https://reproductiverights.org/worldabortionlaws.
} 
It is clear that the content of the judgment itself has little to do with the emergence and spread of the COVID-19 virus. ${ }^{36}$ Because the application to declare the relevant provisions of the Act 1993 unconstitutional was already submitted to the CT in 2019, it is fair to assume that the judgment would have been delivered at some point in the not-so-distant future. Nevertheless, the fact that it was issued at the start of the second wave of the pandemic in Poland is not without significance. It is worth noting that the Tribunal was under no obligation to reach the decision at this point. In fact, in recent years, the average duration of proceedings brought before the Tribunal was two years. However, some cases lasted up to 5 years. ${ }^{37}$ Some commentators observed that the abortion judgment was issued as a distraction from the increasingly obvious crisis affecting the economy and the healthcare system. ${ }^{38}$ Others suggested that the government was hoping that the general restrictions on freedom of movement, introduced at the start of the pandemic, would prevent social unrest. Contrary to such hopes, the announcement of the Tribunal's decision resulted in a long series of spontaneous mass protests across the country and abroad. According to police estimates, on October 28, 2020, 430,000 people attended more than 400 demonstrations around the country, which for some commentators amounted to the largest demonstrations in Polish history, ${ }^{39}$ or at least since the end of Communism starting in $1989 .{ }^{40}$ Initially, the actions of the police were limited to ensuring the safety of the demonstrators. Yet, as protests continued and political pressure grew, the police began blocking the marches, performing identity checks, imposing fines on protesters, or reporting them to the local sanitary and epidemiological stations for breach of COVID-19 restrictions. ${ }^{41}$ According to the Helsinki Foundation, on two separate days of the so-called "Women's Strike," police officers jointly filed 690 penalty motions and sent 727 notes to local sanitary and epidemiological stations. ${ }^{42}$ Civil society organizations reported many arrests and instances of physical violence during the two months of protests following the announcement of the judgment. ${ }^{43}$

According to public authorities, like the police and the National Prosecutor's Office, the use of repressive measures was justified and lawful as it was based on the powers conferred by a series of emergency regulations issued by the government in response to the outbreak of the COVID-19

\footnotetext{
${ }^{36}$ This is unlike a judgment of the Dutch court, which refused to allow the telemedical abortion services. See NetherlandsCourt Rejects Plea for Telemedicine Access to Abortion Pills, InT'L CAMPAign Women's RTs. SAfE Abortion (Apr. 15, 2020), https://www.safeabortionwomensright.org/news/netherlands-court-rejects-plea-for-telemedicine-access-to-abortion-pills/. It is also different from the case that was filed before the Federal Supreme Court in Brazil during the Zika epidemic, which concerned access to abortion on the ground of microcephaly. See Pablo K. Valente, Zika and Reproductive Rights in Brazil: Challenge to the Right to Health, 107 Am. J. PuB. Health 1376 (2017).

${ }^{37}$ Michał Janczura, Powolny Jak... Trybunał Konstytucyjny. Są Sprawy, Które Czekają na Rozpatrzenie Już 5 Lat [Slow as . . . Constitutional Court. There are Cases That Have Been Going on for 5 Years], TOK FM (June, 18, 2019), https://www.tokfm. pl/Tokfm/7,103085,24911449,powolny-jak-trybunal-konstytucyjny-sa-sprawy-ktore-czekaja.html.

${ }^{38}$ Andrzej Stankiewicz, Do Czego Jeszcze Wykorzystać Pandemię? [What Else Can the Pandemic be Used for?], TYGODNIK PowsZechnY (Oct. 26, 2020), https://www.tygodnikpowszechny.pl/do-czego-jeszcze-wykorzystac-pandemie-165377.

${ }^{39}$ Michał Sutowski, Październikowa Rewolucja Godności [The October Revolution of Dignity], KRYTYKA POLITYCZNA (Nov. 9, 2020), https://krytykapolityczna.pl/kraj/michal-sutowski-pazdziernikowa-rewolucja-godnosci/.

${ }^{40}$ Anatol Magdziarz \& Marc Santora, Women Converge on Warsaw, Heightening Poland's Largest Protests in Decades, N.Y. Times (Oct. 30, 2020), https://www.nytimes.com/2020/10/30/world/europe/poland-abortion-women-protests.html; Daniel Tilles, Polish Prosecutors Seek Charges Against Organisers of Abortion Protests for Endangering Public, NoTES From POLAND (Oct. 29, 2020), https://notesfrompoland.com/2020/10/29/polish-prosecutors-seeks-charges-against-organisers-ofabortion-protests-for-endangering-public/.

${ }^{41}$ Human Rights in the Times of a Pandemic. 10 months, 10 rights, 10 restrictions, 10 recommendations for the Future .... HelsinKi Found. Hum. RTs. 1 (Piotr Kubaszewski \& Katarzyna Wiśniewska, eds., 2021).

${ }^{42} I d$.

${ }^{43}$ Szpila Kolektyw, Raport (Anty)Represyjny [An (Anti)Repressive Report], FACEBOOK (Dec. 22, 2020, 1:16PM), https:// www.facebook.com/kolektywszpila/posts/113727750571100; Rzecznik Praw Obywatelskich, Protesty Społeczne po Decyzji ws. Aborcji. RPO Przypomina Rządzącym Standardy Zgromadzeń Spontanicznych [Social Protests After the Decision on Abortion. The Ombudsman Reminds Those in Power of the Standards of Spontaneous Assemblies], RPO (Oct. 23, 2020), https://www.rpo.gov.pl/pl/content/protesty-po-decyzji-aborcji-rpo-przypomina-rzadzacym-standardy.
} 
pandemic. These, in turn, were based on the Act on the prevention and control of infections and infectious diseases in humans 2008 (the Infectious Diseases Act 2008) ${ }^{44}$, which sets the framework within which public authorities can combat the "state of epidemic threat." ${ }^{5}$ Importantly, the government decided not to introduce any of the three types of extraordinary measures foreseen by Article 228 of the Polish Constitution 1997: Martial law, a state of emergency, or a state of natural disaster. ${ }^{46}$ Instead, it employed the provisions of the Infectious Diseases Act 2008 to create a "state of an epidemic" unknown to the Polish Constitution. ${ }^{47}$ By January 2021, the government had issued as many as forty-three regulations interfering with human rights and fundamental freedoms. ${ }^{48}$ These regulations banned the organization of meetings of more than fifty ${ }^{49}$ or five ${ }^{50}$ people, and at some point, suspended the freedom of assembly, guaranteed in Article 57 of the Polish Constitution 1997, ${ }^{1}$ altogether with the exception of religious gatherings. ${ }^{52}$ Consequently, public authorities used the emergency powers assumed or created in response to COVID-19 in order to suppress the protests that followed the announcement of the abortion judgment $\mathrm{K} 1 / 20$. In addition, according to the National Prosecutor's Office, protesters were warned of the possibility of receiving criminal sanctions for posing a threat to the life and health of others, an offense punishable under Article 165 (1) of the Criminal Code by of up to eight years of imprisonment. ${ }^{53}$

The Polish Commissioner for Human Rights ${ }^{54}$ and the Helsinki Foundation ${ }^{55}$ rejected such justification, claiming that the actions and the legal basis for these actions were unconstitutional. This interpretation was supported by the jurisprudence of several lower courts, which declared that in trying to impose restrictions on freedom of movement and assembly, public authorities acted ultra vires. According to the District Court for Warsaw-Śródmieście, only the introduction of one of the extraordinary measures foreseen by the Constitution, especially the state of natural

\footnotetext{
${ }^{44}$ Art. 46 ust 4, 46b (Pol.), https://lexlege.pl/ustawa-o-zapobieganiu-oraz-zwalczaniu-zakazen-i-chorob-zakaznych-u-ludzi/ art-46/; Dz.U. 2008.234.1570 ze zm (Pol.).

${ }^{45}$ Dz.U. 2020.1845 ze zm (Pol.).

${ }^{46}$ It is commonly accepted that the decision not to introduce the state of emergency was not dictated by ad hoc political interest of the ruling party to secure a second term for the sitting president, Andrzej Duda. This would have been constitutionally impossible had the state of natural disaster been announced. Following Article $228 \$ 7$, during state of emergency, as well as ninety days following its termination, it is prohibited to hold elections to the Sejm, Senate, Presidency, or organs of local government. This provision gained importance in Spring 2020, as the beginning of the COVID-19 pandemic coincided with the presidential campaign in Poland. As the Law and Justice party candidate, the sitting president Andrzej Duda, was leading in the opinion polls, this would mean having to postpone the elections and risk a defeat as a result of what was clearly becoming a serious healthcare and economic crisis. Perhaps even more relevant is the fact that, according to Polish law, the introduction of extraordinary measures would allow everyone, including entrepreneurs, to obtain compensation from the state for the material damage suffered as a result of the restriction of their civil rights during the state of emergency. See Dz. U. 2002.233.1955 (Pol.).

${ }^{47}$ Dominika Sitnicka, "Udział w Zgromadzeniach Podczas Epidemii nie jest Nielegalny. Policja Masowo Przegrywa w Sądach" [Attending Assemblies During an Epidemic is not Illegal. The Police are Losing Massively in the Courts], OKO PRESS (Dec. 15, 2020), https://oko.press/zgromadzenia-legalne-policja-mandaty/.

${ }^{48}$ Helsinki Found., supra note 41, at 70.

${ }^{49}$ Dz. U. 2020.433 ze zm (Pol.). This was followed by the Regulation of the Minister of Health of March 20, 2020, on the declaration of the state of pandemic in the Republic of Poland. Dz. U. 2020. 491 ze zm (Pol.).

${ }^{50}$ Dz. U. 2020.2316; Dz. U. 2021.512 ze zm (Pol).

${ }^{51}$ Dz. U. $1997 \mathrm{nr} 78$ poz. 483 (Pol.).

${ }^{52}$ Dz. U. 2020.658 (Pol.).

${ }^{53}$ Leszek Rudziński, Prokuratura Chce Ścigać Organizatorów Protestów ws. Aborcji. Grozić ma im Nawet 8 Lat Więzienia [The Prosecutor's Office Wants to Pursue the Organizers of the Abortion Protests. They are to be Threatened with up to 8 Years in Prison], POLSKA TIMES, (Oct. 29, 2020), https://polskatimes.pl/prokuratura-chce-scigac-organizatorow-protestowws-aborcji-grozic-ma-im-nawet-8-lat-wiezienia/ar/c1-15262850.

${ }^{54}$ Agnieszka Jędrzejczyk, "Po 500 zł za Udział w Zgromadzeniu Przed Biurem Poselskim, Brak Maseczki i Wykrzykiwane Hasła. Kasacja RPO do SN" [Fined 500 Zlotys Each for Participation in the Assembly in Front of the Deputy's Office, No Mask and Shouted Slogans. Deletion of the RPO to the SN], RPO (May 20, 2021), https://www.rpo.gov.pl/pl/content/po-500-zludzial-w-zgromadzeniu-przed-biurem-poselskim-brak-maseczki-hasla-kasacja-RPO-SN.

${ }^{55}$ HeLsINKI Found., supra note 41, at 18.
} 
disaster, ${ }^{56}$ would allow for the curtailment of rights such as personal freedom and the freedom of movement on the territory of Poland.$^{57}$ Consequently, the court held that the government's decision "not to introduce the state of natural disaster, which corresponds to the current situation related to the coronavirus, means that the prohibitions stipulated in the [government] Regulations should be considered unconstitutional and therefore devoid of any legal basis". ${ }^{58}$ Furthermore, both Polish courts and the Helsinki Foundation pointed out that because a state of natural disaster had not been declared, the restrictions and sanctions imposed on protesters were incorrect or disproportionate, as they went beyond a statutory authorization provided in the Infectious Diseases Act 2008. ${ }^{59}$

On the one hand, it could be argued that the situation in Poland is not unique. As noted by the Democracy Reporting International ${ }^{60}$ and the Office for Security and Cooperation in Europe (OSCE) Office for Democratic Institutions and Human Rights, ${ }^{61}$ governments in most European countries used the COVID-19 pandemic to extend their powers. Some states, like Hungary and the Czech Republic, did so by introducing the state of emergency and extending it by means that may be unconstitutional. Other states, such as Austria and Slovenia, used existing powers beyond their intended purpose. ${ }^{62}$ Others, such as Cyprus and Belgium, based their actions on outdated laws. Some others, for example, Denmark, Estonia, or Finland, took decisions without an appropriate legal basis. ${ }^{63}$ Consequently, the regulatory solutions adopted by the Polish government in response to COVID-19 do not diverge from the more general trend witnessed in other countries. What is more, there is some evidence to suggest that lower courts have upheld the rule of law, quashing cases initiated against the protesters. On the other hand, however, the abortion judgment and events in its aftermath placed in sharp relief the extent to which the government is ready to take actions outside and in clear contravention of the law to protect what it defines as a public good, public order, and the state itself. First, the government utilized the outbreak of COVID-19 in order to secure extended executive powers. Subsequently, it used these powers to suppress protests concerning reproductive rights. Such protests and other forms of social mobilization have long been of vital importance in resisting conservative attempts to restrict reproductive rights. Tellingly, in the early days of the protests, the Leader of the Law and Justice Party, Jarosław Kaczyński, called public authorities and his supporters to oppose the protesters and defend the Polish churches and patriotism "at any cost."

In this respect, unlike in other countries, the refusal to introduce one of the Constitution's "extraordinary measures" providing the government with emergency powers raises concerns.

\footnotetext{
${ }^{56}$ The definition of a natural disaster includes the mass occurrence of infectious diseases in humans under Article 3(1)-(2). See DZ. U. 2017.1897 (Pol.).

${ }^{57}$ Although the case concerned different protests organized in Spring 2020 against COVID-19 regulations, the court's reasoning could be applied to the actions of public authorities during abortion protests. See [District Court] [WarsawŚródmieście] sygn. akt V W 1847/20 (Pol.).

${ }^{58}$ Sygn. Akt V W 1847/20 (Pol.).

${ }^{59}$ Helsinki Found., supra note 41. See also Sądu Najwyższego Izby Karnej z 1 lipca 2021 r., sygn. akt IV KK 238/21; Sąd Rejonowy w Rzeszowie, sygn akt II W 539/20 (Pol.); Sąd Rejonowy dla Warszawy-Śródmieścia, sygn. akt V W 2077/20 (Pol.); Sąd Rejonowy dla Warszawy-Śródmieścia, sygn. akt V W 2519/20 (Pol.); Sąd Rejonowy dla Warszawy-Śródmieścia, sygn. akt V W 2757/20 (Pol.); Sąd Rejonowy dla Warszawy-Śródmieścia, sygn. akt V W 2071/20 (Pol.); Sąd Rejonowy dla WarszawyŚródmieścia, sygn. akt V W 1083/20 (Pol.).

${ }^{60}$ Extraordinary or Extralegal Responses? The Rule of Law and the COVID-19 Crisis, DEMOCRACY REPORTING INT'L (May 2021), https://democracy-reporting.org/dri_publications/extraordinary-or-extralegal-responses-covid-19-and-the-rule-oflaw-in-the-eu/.

${ }^{61}$ OSCE Office for Democratic Institutions and Human Rights (ODIHR), OSCE Human Dimension Commitments and State Responses to the Covid-19 Pandemic (2020).

${ }^{62} I d$. at 25.

${ }^{63} I d$.

${ }^{64}$ Kałużyński Sebastian, Kaczyński Wzywa do Wojny z Kobietami. Tekst Oświadczenia, Słowo w Słowo (Co Jedno to Gorsze) [Kaczyński Calls for a War with Women. The Text of the Statement, Word for Word (Which is Worse)], OKO PRESS (Oct. 27, 2021), https://oko.press/kaczynski-wzywa-do-wojny-z-kobietami-tekst-oswiadczenia/.
} 
While the Polish Constitution 1997 permits extensive restrictions of civil and political rights during the state of emergency, it simultaneously establishes clear temporal and substantive boundaries with regard to government actions in such cases. ${ }^{65}$ As noted by the OSCE, the existing legislation to fight communicable diseases and epidemics does not provide for clear limitations in terms of the duration of the emergency measures, even if they de facto involve the curtailment of human rights. ${ }^{66}$ So far, Polish courts have held the decisions of public authorities limiting constitutional rights and freedoms disproportionate, unlawful, or even unconstitutional. However, as other decisions reach increasingly politicized courts ${ }^{67}$ the legal situation might change. Consequently, the government's decision not to introduce the extraordinary constitutional measures could lead to a permanent_albeit informal and unconstitutional "state of emergency"perhaps legitimated by the judiciary in the future. ${ }^{68}$ This could have devastating consequences for the future development of reproductive rights in Poland. As illustrated by the health regulations adopted at the beginning of the COVID-19 outbreak and by the decision to announce the abortion judgment, states of emergency, in which the rule of law is weakened or suspended, can easily be-and often are-utilized to pursue radical reproductive rights agendas. However, as argued above, such changes do not occur in a vacuum. They stem from much longer and more established-even if not always visible-patterns and forms of government related to the rule of law. The next two sections of the Article examine these patterns and forms of government and the way in which they influenced abortion judgment K1/20. The next section focuses on the anticonstitutional backsliding that could be observed in Poland in recent years. The section that follows focuses on much broader phenomena of legal culture and superficial institutionalization of the rule of law more generally. Both sections treat the judgment as a focal point for the analysis.

\section{Midterm Factors: Abortion in Times of Anti-Constitutional Populist Backsliding 1. Poland's Successful Democratic Transition?}

The Polish transition has been a long process, the symbolic start of which is usually associated with the so-called Round Table-negotiations between the government and the opposition that took place in spring 1989. This event led to elections in June 1989, which brought the decisive defeat of the ruling Polish Workers' Party and the change of the political and socio-economic system. The first years following the collapse of state Socialism were marked by intensely neoliberal reforms that resulted in the pauperization of large strata of society, deep political fragmentation, and the emergence of the Catholic Church as a powerful political actor. However, Poland was seen as an example of a successful transition to democracy due to the progressing entrenchment of principles commonly associated with liberal democracies, including free market economy, free elections, and free media, and the rule of law. They were all adopted as guiding principles of the legal system, first in the Constitutional Act regulating the relationship between the legislative

\footnotetext{
${ }^{65}$ In particular, under Article 232 of the Constitution, the state of natural disaster can only be introduced for a period of up to thirty days and can be prolonged with the Parliament's consent. The state of emergency can be introduced for a period of no longer than ninety days and can only be extended once with consent of the Parliament for a period no longer than sixty days.

${ }^{66}$ OSCE ODIHR, supra note 61, at 36.

${ }^{67}$ The governing Law and Justice (PiS) party has attempted to subject the judiciary to political pressure and control. In 2019 , the first reports of persecution of individual judges began. By early 2020, judges who criticized the government's overhaul or simply applied European Union (EU) law correctly were subjected to disciplinary action. See Małgorzata Gersdorf \& Mateusz Pilich, Judges and Representatives of the People: A Polish Perspective, 16 Eur. Const. L. Rev. 345 (2020).

${ }^{68}$ The problem of whether the situation created by the Polish government constitutes a state of emergency as defined by Schmitt as "the suspension of the entire existing order, in which it is clear that the state remains, whereas law recedes" will not be discussed here. Questions of whether the regulation of reproductive rights is connected to "the state of emergency" and to what extent persons who refuse to accept traditional reproductive roles constitute "enemies" in the Schmittian sense may warrant separate analysis elsewhere. See CARL SCHMitT, Political Theology, in Four Chapters ON THE CONCEPT OF SOVEREIGNTY, 12 (George Schwab trans., 1985).
} 
and executive powers and the local government 1992, "The Small Constitution," and subsequently in the Constitution of the Polish Republic 1997. By 2002, Carothers noted that Poland was among states "en route to becoming successful, well-functioning democracies." 69 The Polish accession to the European Union in 2004 was considered the apogee of the democratization processes. The fact that Poland was allowed to join the EU meant that it was considered a polity that guaranteed the rule of law. The rule of law was defined as "legality, which implies a transparent, accountable, democratic and pluralistic process for enacting laws; legal certainty; prohibition of arbitrariness of the executive powers; independent and impartial courts; effective judicial review including respect for fundamental rights; and equality before the law." ${ }^{\prime 0}$ As noted by Sadurski, Poland and Hungary were seen as polities whose level of democratic institutionalization was unprecedented in their entire histories. For the first time, they enjoyed a combination of democratic governance, rapid economic growth, and rising standards of living, as well as international safety. ${ }^{71}$

Perhaps, for this reason, liberal politicians and commentators were shocked when in 2015, the Law and Justice Party won first the Presidential and then the Parliamentary elections, securing control of the main centers of power. ${ }^{72}$ What Poland has experienced since then has been described as "anti-democratic populist backsliding" or "erosion." It has often been compared to parallel processes in Hungary, Brazil, India, or Turkey. ${ }^{73}$ Analyzing these processes in Poland, Sadurski noted that the accelerated changes, which resembled parallel developments in Hungary, included the following: Radical legislative changes, which aimed at seizing control of the public media, the apex courts, important judicial and administrative bodies, for example, the National Council for the Judiciary, attacks on NGOs, and anti-European rhetoric. As noted by Bucholc, as a result of these actions aimed to increase the power available to the Parliament, there was "a factual shift from a multicentric figuration of the main state organs towards a monocentric structure. The state executive, comprising the president, the prime minister, all the ministers and the respective administrative bodies, all belong to the PiS [Law and Justice Party - AK] sphere of influence." 74 The processes were described as unconstitutional because they were conducted through multiple breaches of the Constitution 1997 and a series of de facto changes to the Constitution via statutes. Yet, the Law and Justice party has actively sought popular legitimacy by proclaiming unity and community as paramount social values. ${ }^{75}$ It has also projected a series of clearly defined enemies as part of this process of populist self-legitimization. Such enemies include immigrants, feminists, the LGBT+ community, and women wanting to control over their reproductive decisions.

\section{The Judgment K 1/20 — a Reflexive Lens of the Anti-Constitutional Backsliding}

Prima facie, the CT (K 1/20) judgment, issued in October 2020, can be seen as part of the PiS project. While originally the party was rather moderate in its demands concerning reproductive

\footnotetext{
${ }^{69}$ Carothers Thomas, The End of the Transition Paradigm, 13 J. Democracy 5, 9 (2002).

${ }^{70}$ Communication from the Commission to the European Parliament and the Council, Press Release, Introducing a New EU Framework to Strengthen the Rule of Law in the Member States, COM 158 (2014). See also "Respect for the rule of law was one of the criteria for accession to the European Union”, EUR. CoMm'N. (last updated Nov. 5, 2021), https://ec.europa.eu/ neighbourhood-enlargement/policy/glossary/terms/accession-criteria_en.

${ }^{71}$ SADURSKI, supra note 6.

${ }^{72}$ The party was founded by Lech Kaczyński and Jarosław Kaczyński in 2001, as a centrist and Christian democratic party, following a split from the Solidarity Electoral Action (AWS). It held power between 2005 and 2007 together with the League of Polish Families (LPR) and Self-Defence of the Republic of Poland (SRP). Therefore, it was not the emergence of the party as an important political player but the scale of its victory that took commentators by surprise.

${ }^{73}$ Tímea Drinóczi \& Agnieszka Bień-Kacała, Illiberal Constitutionalism: The Case of Hungary and Poland. 20 GERMAN L. J. 1140 (2019). See also SADURSKI, supra note 6; Pech \& Scheppele, supra note 7; Varol, supra note 5.

${ }^{74}$ Marta Bucholc, The Polish Constitutional Crisis 2015-16: A Figurational Perspective, 5 Human Figurations: Long-Term Perspectives on the Human Condition 2 (2016).

${ }^{75}$ SADURSKI, supra note 6, 20-21.
} 
rights, ${ }^{76}$ the political dependence on the Catholic Church and the competition with highly reactionary political factions led to its rapid radicalization. Consequently, since its assumption of power, the party has mounted an offensive against reproductive rights and openly supported numerous attempts to restrict even further the already restrictive abortion law. In 2016, a few months after it came to power, the Prime Minister admitted that the government would support a total ban on abortion. At the same time, an ultra-Conservative organization, Ordo Iuris, prepared a legislative proposal according to which abortion would constitute a crime in all but one case: If the death of the fetus was a consequence of an action aiming to avert a direct threat to the woman's life. 2018 brought another wave of legislative proposals aimed at a total ban on abortion. These initiatives triggered mass protests, especially in October 2016 and March 2018, which have become regular events known as "Women's Strike."77 Owing to these protests, different legislative projects of more draconian abortion laws collapsed in Parliament over the years, most recently in April 2020. This is the reason why, in 2019, a group of 119 Conservative MPs chose the route of constitutional complaint to achieve such changes. By then, the government had acquired control of the CT, and it determined the outcome of the decision. As such, the judgment $\mathrm{K} 1 / 20$ constitutes a perfect illustration of the broader patterns of government that have dominated Polish politics in recent years. The following sub-sections show the impact of these structural (anti-constitutional) changes on abortion law.

\section{Independent Constitutional Judiciary}

The CT was established in 1982, at the height of repressive martial law. ${ }^{78}$ Initially, it was expected to play a minor advisory role for the government. Yet, as observed by Sadurski, "after 1989, the CT in the absence of a comprehensive and coherent constitution, became an active partner and controller of the legislature and the executive" and "a robust defender of rights and liberties." It played an important role in the process of democratization and the establishment of the rule of law. Its gap-filling function is best reflected in a judgment issued by the court in 1990 (K 7/90). Taking a general clause in the amended Constitution of the Polish People's Republic 1952 that set out "the rule of law," the CT derived the principle of retroactivity, protection of vested rights, and what it called "the principle of citizens confidence in the state." ${ }^{80}$ However, like all public bodies, its operation depends on the collaboration and support of other parts of the system. According to the Constitution 1997, the CT judges are elected by the Sejm - by a simple majority - for a term of nine years and they are sworn in by the President. The Tribunal cannot act on its own accord because proceedings are initiated by third parties such as MPs, the President, and citizens. The Tribunal has the power to declare a legal provision or an act unconstitutional, which eliminates it from the legal system. The judgment takes effect from the day of its publication in the official journal, which should take place immediately after its announcement. The judgments of the Tribunal are universally binding and final. ${ }^{81}$ Since 2015 , the current government has systematically tampered with all these basic requirements determining the constitutional position,

\footnotetext{
${ }^{76} \mathrm{It}$ is worth remembering that issue of abortion had led to a split in the party and a departure of a small number of conservative MPs in the late-2000s.

${ }^{77}$ Julia Kubisa \& Katarzyna Rakowska, Was it a Strike? Notes on the Polish Women's Strike and the Strike of Parents of Persons with Disabilities, 30 Praktyka Teoretyczna, 15 (2018); Elżbieta Korolczuk, Counteracting Challenges to Gender Equality in the Era of Anti-Gender Campaigns: Competing Gender Knowledges and Affective Solidarity, 27 SOC. POL.: INT'L STUD. GENDER, STATE \& SOC'Y 694, 696 (2020).

${ }^{78}$ Martial law was introduced by the communist government on December 13, 1981 and lasted until July 22, 1983, and the executive power was transferred to the Military Council of National Salvation (WRON). As a result, everyday life activities, including communication or freedom of movement, were restricted, and opposition movements, such as Solidarity were delegalized.

${ }^{79}$ SADURSKI, supra note 6 , at 42 .

${ }^{80}$ SADURSKI, supra note 6 , at 43 .

${ }^{81}$ Constitution of the Republic of Poland Apr. 2, 1997, arts. 188-97.
} 
legitimacy, and effectiveness of the Constitutional Tribunal. This problem has been discussed in great length by many commentators ${ }^{82}$ and the Venice Commission of the Council of Europe. ${ }^{83}$

First, as soon as the Law and Justice party won the elections in 2015, the parliamentary majority canceled the appointment of the five CT judges made by the previous Parliament, using allegations that the latter acted ultra vires. Five new judges were elected, sworn by the President, and immediately escorted to the court's buildings to take office. These events took place the night before the CT issued a decision in which it held that three of the five appointments made by the previous Sejm were unconstitutional. Violating constitutional principles and practice, the President refused to acknowledge the Tribunal's decision and to swear the three judges whose appointment by the previous Parliament was held constitutional. The President's actions led to a situation where the judges elected constitutionally were not sworn in and could not take office, while the judges whose election was deemed unconstitutional were physically present in the Tribunal. Thus, a situation emerged where "the valid norm has no force and decisions, which are not legal, do have the force of law." 84 These events sparked a protracted conflict between the CT and the Parliament; a battle that included the adoption of a series of legislative acts concerning the functioning of the Tribunal and another constitutionality review, in which the Tribunal had to assess some of the constitutionality of the new provisions, even adjudication in its own case. The conflict was brought to an end by the retirement of the President of the Tribunal, Andrzej Rzepliński, at the end of 2016. The newly appointed President of the court, Julia Przyłębska-one of the judges elected unconstitutionally - in a number of decisions related to the everyday working of the Tribunal, suspended three further judges appointed in 2010 and forced one to take leave of absence. Ever since, the CT has been under the control of the ruling party.

These developments go a long way to explaining the reasons behind the abortion judgment $\mathrm{K} 1 / 20$. Moreover, they also cast serious doubts on its legality and validity. The Helsinki Foundation for Human Rights has argued that, according to Polish constitutional law, the recent decision taken by the judges currently sitting on the bench should not be recognized as a judicial ruling, and it does not have legal force. ${ }^{85}$ Both the Helsinki ${ }^{86}$ and the Batory Foundation ${ }^{87}$ argued that, according to Polish constitutional law, the recent decision should not be recognized as a judicial ruling. According to this interpretation, the judges who issued the decision are not judges according to the law-who do not represent public authorities - which constitutes a flaw of such magnitude that renders the judgment non-existent. ${ }^{88}$ Thus, as the judgment does not exist in the

\footnotetext{
${ }^{82}$ Leszek Garlicki, Sady a Konstytucja Rzeczypospolitej Polskiej [Courts and the Constitution of the Republic of Poland], Przegląd SĄDOwy 7 (2016); Wojciech Sadurski, Polish CT Under PiS: From an Activist Court to a Paralysed Tribunal, to a Governmental Enabler, 11 HAGUE J RULE L. 63 (2018).

${ }^{83}$ European Commission, European Commission for Democracy Through Law (Venice Commission) \& The Directorate General of Human Rights and Rule of Law (DGI) of the Council of Europe, Poland, Joint Opinion on Amendmentsto the Law on the Common Courts, the Law on the Supreme Court, and Some Other Laws, Opinion No. 977 / 2019,

CDL-PI(2020)002 (Jan. 16, 2020), https://www.venice.coe.int/webforms/documents/default.aspx?pdffile=CDL-PI(2020) 002-e.

${ }^{84}$ Dani Filc \& Hadas Ziv, Exception as the Norm and the Fiction of Sovereignty: The Lack of the Right to Health Care in the Occupied Territories, in EvIL, LAW AND THE STATE 71 (John T. Parry ed., 2006).

${ }^{85}$ Constitutional Tribunal Act-The Monitoring of Legislative Amendments, HeLsinki Found. (Nov. 24, 2015), https:// www.hfhr.pl/en/constitutional-tribunal-act-the-monitoring-of-legislative-amendments/.

${ }^{86}$ Stanowisko Helsińskiej Fundacji Praw Człowieka ws. tak zwanego orzeczenia Trybunału Konstytucyjnego [The position of the Helsinki Foundation for Human Rights regarding the so-called ruling of the Constitutional Tribunal] HELSINKI Found. (Oct. 22, 2020), https://www.hfhr.pl/stanowisko-helsinskiej-fundacji-praw-czlowieka-ws-tak-zwanego-orzeczenia-trybunalukonstytucyjnego/.

${ }^{87}$ Statement by the Legal Experts Group of the Stefan Batory Foundation on the Constitutional Tribunal Ruling on Abortion, BATORY Found. (Oct. 28, 2010), https://www.batory.org.pl/en/oswiadczenie/statement-by-the-legal-experts-group-of-thestefan-batory-foundation-on-the-constitutional-tribunal-ruling-on-abortion/.

${ }^{88}$ Marcin Dąbrowski, Wyroki TK z udziałem osób nieuprawionych do orzekania [Constitutional Tribunal Judgments Involving Persons Who are Not Entitled to Adjudicate], in Konstytucjonalizm Polski: Refleksje z OKazjI Jubileuszu 70-Lecia Urodzin in 45-Lecia Pracy Naukowej Profesora Andrzeja Szmyta [Polish Constitutionalism: Reflections
} 
legal sphere, it cannot generate any legal consequences, rights, or obligations. Accordingly, civil society organizations called upon doctors and law enforcement agencies to ignore this judgment. Though some members of the legal profession have argued that the judgment should be characterized not as non-existent, but as void due to faults stipulated by the Code of Civil Proceedings; for example, the composition of the court violated legal provisions. ${ }^{89}$ The distinction is crucial. If the second interpretation is applied, the judgment will be legally effective until its faults are established in separate proceedings and the decision is rendered void by a court. ${ }^{90}$ While the second interpretation arguably promotes certainty in the legal system, it might have devastating consequences for women's reproductive rights.

Given that the Public Prosecution Office in Poland is hierarchically subordinate to the government, we can expect a rise in criminal litigation against healthcare professionals and other persons trying to help women access abortion services on the grounds of fatal fetal abnormality. Anecdotal evidence suggests that, to date, lower courts in Poland-while accepting that the CT decisions are flawed-have been reluctant to declare them non-existent. ${ }^{91}$ This means the judgment $\mathrm{K} 1 / 20$ will most probably be treated as legally effective. While some more defiant courts may find ways to quash proceedings against medical professionals, the judgment will inevitably have a further chilling effect on the provision of abortion services in Poland. More importantly, it is very difficult to imagine a case in which a court would impose a duty on a doctor to perform an abortion in a case of fatal fetal abnormality. First, the judicial process is often too slow to respond to time-sensitive matters like abortion. Second, cases in which such decisions have been issued even before the recent changes in the law have been scarce and far between. Third, regardless of the problems concerning its legality and validity, the judgment itself presents problems of its own and reveals the way, in which politicians and lawyers supporting the ruling party perceive the role of law as subordinate to politics.

\section{Rules of Judicial Interpretation and the Protection of Constitutional Rights}

The two hundred-page long judgment, published with a three-month delay, fails to meet the basic standards of judicial and constitutional interpretation. First of all, the court agreed with the applicants, who claimed that the challenged provision, Article 4a (1) \& (2) of the Act 1993 legalized "eugenic practices in relation to the unborn child." It found that the provision violates Article 38 in connection with Article 30 and Article 31 Paragraph 3 of the Polish Constitution 1997. These provisions guarantee respectively: a) legal protection of every person's life; b) respect for and protection of human dignity; and c) the principle of proportionality. The Tribunal found that the protection of every person's life guaranteed in Article 38 of the Constitution $1997^{92}$ encompassed the entire "biological existence of the human being" from the moment of conception. Employing a wide interpretation of this provision, read in conjunction with Article 30 guaranteeing respect for human dignity, the judges came very close to equating the constitutional provision for the "legal protection of everyone's life" with the right to life of the fetus. The Tribunal suggested that, for abortion to be justified, it needs to meet the standard of "absolute necessity." This was taken to mean that the protection of the fetus's life cannot be limited to protect rights and values of

\footnotetext{
on the 70th Anniversary of Birth and 45th Anniversary of Scientific Work of Professor Andrzeja Szmyta] (Agnieszka Gajda, Krzysztof Grajewski, Anna Rytel-Warzocha, Piotr Uziębło, \& Marcin Michał Wiszowaty eds., 2020).

${ }^{89}$ Article 379 of the Code of Civil Proceedings (Dz. U. 1964.43.296 ze zm.) can be applied based on Article 36 of the Act on the Organisation and Mode of Proceedings before the Constitutional Tribunal (Dz. U. 2016.2072 ze zm.).

${ }^{90}$ Dąbrowski supra note 88. See also Ewa Łętowska, Wokół Wyroku Trybunału Konstytucyjnego w Sprawie Aborcji [Around the Constitutional Tribunal's Judgment on Abortion], KonstyTUCYjNY.PL. (Nov 6, 2020), https://konstytucyjny.pl/ewaletowska-wokol-wyroku-trybunalu-konstytucyjnego-w-sprawie-aborcji/.

${ }^{91}$ Dąbrowski, supra note 88 .

${ }^{92}$ For English translation, see The Constitution of the Republic of Poland, SEJM, (Apr. 2, 1997), https://www.sejm.gov.pl/ prawo/konst/angielski/kon1.htm.
} 
"lower standing," which include the right to property, other economic rights, and even the health of others.

However, Article 38 of the Constitution has been interpreted contrary to the intentions of its original drafters. During the Constitutional Assembly in 1996, there were heated debates about whether to include the phrase "from the moment of conception" in the Article protecting life. However, the Assembly decided against it. ${ }^{93}$ Therefore, the interpretation provided by the Tribunal is contrary to the principles of historical, systemic, and teleological legal interpretation. The judges also read selectively earlier judgments of the CT on the right to life. In particular, they based their reasoning on an earlier judgment concerning abortion, K 26/96, issued in 1997 on the basis of the "Small Constitution" 1992. While the judges correctly identified conservative aspects of the judgment, they failed to recognize the qualifications made by the judges at the time with regard to the protection of human life. ${ }^{94}$ This unsophisticated reading of the Constitution 1997 employed by the current Tribunal suggests that abortion on the grounds of rape or incest-and even abortions to save the mother's health-could be deemed unconstitutional. It creates a situation in which abortion rights can now easily be subject to further curtailment. Indeed, the representatives of anti-abortion groups in Poland have already implied that a new motion will be filed with the Tribunal, aiming to strike down the provision permitting abortion in cases of rape or incest. ${ }^{95}$ At the same time, some have argued that the judgment still allows for abortion on the grounds of fatal fetal abnormality if it poses a risk to the health and life of the mother. ${ }^{96}$ This is certainly a possibility, although it will be a challenge to persuade the medical profession to follow this kind of interpretation.

Second, the entire judgment revolved around consideration of the rights and interests of the fetus. The constitutional rights of women, including the guarantee of human dignity, ${ }^{97}$ the right to freedom, ${ }^{98}$ the right to life, ${ }^{99}$ the prohibition of torture and degrading treatment, ${ }^{100}$ the right to privacy, ${ }^{101}$ and the protection of health ${ }^{102}$ were barely mentioned in the judgment. The judges went so far as to claim that Article 71 Paragraph 2 PC 1997-guaranteeing special assistance of public authorities to a "mother, before and after birth" gives rise to an obligation of the state to protect the life of the fetus. At the same time, they suggested that the "discomfort" caused by giving birth to a child with severe disabilities or illness cannot possibly take priority over the obligation to protect the life and dignity of the fetus. In other words, the mother's discomfort and general "well-being" were weighted against such constitutional values as the fetus's right to life

\footnotetext{
${ }^{93}$ Komisja Konstytucyjna Zgromadzenia Narodowego, Biuletyn XLV, Warszawa 1997, s. 3-46.

${ }^{94}$ The CT in the case K 26/96 held that, “. . . the statement that human life at every stage of its development constitutes a constitutional value subject to protection does not mean that the intensity of this protection in every phase of life and in all circumstances has to be the same." See OTK ZU 1997/2/19 (Pol.).

${ }^{95}$ See Natalia Waloch, Kaja Godek Idzie za Ciosem. Chce, by Zgwałcone Kobiety Tez Rodzity [Kaja Godek Goes After the Blow. He Wants Raped Women to Give Birth Too], WYborzCA.PL (Oct. 23, 2020), https://www.wysokieobcasy.pl/wysokieobcasy/7,100865,26427308,kaja-godek-idzie-za-ciosem-chce-by-zgwalcone-kobiety-tez-rodzily.html.

${ }^{96}$ Maciej Gutowski \& Piotr Kardas, Trybunał Konstytucyjny nie Mógł Rozstrzygnąć Gorzej, Czyli o Dewastacji Systemu Jednym Rozstrzygnięciem [The Constitutional Tribunal Could Not Decide Worse, i.e., the Devastation of the System, with One Decision], PALESTRA (2020), https://palestra.pl/pl/czasopismo/wydanie/10-2020/artykul/trybunal-konstytucyjny-niemogl-rozstrzygnac-gorzej-czyli-o-dewastacji-systemu-jednym-rozstrzygnieciem; Rafał Adamus, Przesłanka Eugeniczna (Embriopatologiczna) Jako Przesłanka Legalnego Przerywania Ciaży-Glosa do Wyroku Trybunału Konstytucyjnego z 22.10.2020 (K1/20) [Eugenic Premise (Embryopathological) Premise as a Premise for Legal Termination of PregnancyGloss to the Judgment of the Constitutional Tribunal of October 22, 2020 (K1 / 20)], PALESTRA (2020), https://palestra. $\mathrm{pl} / \mathrm{pl} /$ czasopismo/wydanie/11-2020/artykul/przeslanka-eugeniczna-embriopatologiczna-jako-przeslanka-legalnego-przerywaniaciazy-glosa-do-wyroku-trybunalu-konstytucyjnego-z-22.10.2020-r.-k-1-20.

${ }^{97}$ Constitution of the Republic of POland, art. 30.

${ }^{98} \mathrm{Id}$. at art. 31(1).

${ }^{99} \mathrm{Id}$. at art. 38.

${ }^{100} I d$. at art. 40.

${ }^{101} I d$. at art. 47.

${ }^{102} I d$. at art. 68.
} 
and dignity. There was no mention of the fact that the suffering and the pain of the pregnant person, during and after pregnancy, would amount to inhumane and degrading treatment, prohibited by the Constitution.

Third, the Tribunal referred in a very limited way to international human rights standards, and it did so selectively and erroneously. For example, it briefly referred to Article 2 of the European Convention on Human Rights (ECHR), Article 2 and Article 3 of the Charter of Fundamental Rights of the EU, and Article 10 of the UN Convention on the Rights of Persons with Disability. In so doing, it argued that the lack of "temporal scope" of these provisions suggests that human life could and should be protected from conception. Yet, the judges misinterpreted those human rights provisions, ignoring the case law and opinions produced by the human rights bodies, such as the European Court of Human Rights ${ }^{103}$ the Committee on the Elimination of Discrimination against Women $(\mathrm{CEDAW})^{104}$, and the UN Human Rights Committee. ${ }^{105}$ While these bodies have been reluctant to acknowledge the right to abortion, ${ }^{106}$ in $V o v$. France the ECtHR has clearly stated that: "at best, [the embryo's/foetus'] potential and capacity to become a person required protection in the name of human dignity, without making it a person with the right to life for the purposes of Article 2". ${ }^{107}$ The CT further ignored important documents such as the General Comment no. 22 (2016) on the Right to sexual and reproductive health, Article 12 of the International Covenant on Economic, Social and Cultural Rights, ${ }^{108}$ and the General comment No. 36 (2018) on Article 6 of the International Covenant on Civil and Political Rights, on the right to life. ${ }^{109}$ Both documents speak about the need for safe abortion care and the elimination of restrictive abortion laws.

Finally, and most crucially, the Tribunal acted ultra vires. Two judges submitted dissenting opinions, arguing that, in issuing this ruling, the Tribunal was acting ultra vires, as, by striking down the provision of Article 4a (1) \& (2) of the Act 1993, which decriminalizes a certain type of activity, it had established a new type of criminal offense in the Criminal Code 1997. This, in turn, they argued, violated the Polish Constitution of 1997, which requires that new offenses must be created exclusively by statute. ${ }^{110}$ Moreover, according to the dissenting opinions, the Tribunal had in recent years become an instrument utilized by politicians to change legislation in controversial matters, where attempts in Parliament to revise legislation or the Constitution had been unsuccessful. On this analysis, the majority judgment allowed legislative changes to be introduced

\footnotetext{
${ }^{103}$ Vo v. France [GC], 2004 VIII, Eur. Ct. H.R. http://hudoc.echr.coe.int/fre?i=002-4246.

${ }^{104}$ Committee on the Elimination of Discrimination Against Women (CEDAW), Office of the United Nations High Commissioner for Human Rights (OHCHR), Report of the Inquiry Concerning the United Kingdom of Great Britain and Northern Ireland Under Article 8 of the Optional Protocol to the Convention on the Elimination of All Forms of Discrimination Against Women (Feb 23, 2018), https:/tbinternet.ohchr.org/Treaties/CEDAW/Shared\%20Documents/ GBR/INT_CEDAW_ITB_GBR_8637_E.pdf.

${ }^{105}$ U.N. Human Rights Committee, Views adopted by the Committee under article 5 (4) of the Optional Protocol, concerning communication No. 2324/2013, U.N. Comm'n, U.N. Doc. CCPR/C/116/D/2324/2013 (Nov. 17, 2016); U.N. Human Rights Committee, Views adopted by the Committee under article 5 (4) of the Optional Protocol, concerning communication No. 2425/2014, U.N. Comm'n, U.N. Doc. CCPR/C/119/D/2425/2014 (July 11, 2017).

${ }^{106}$ Magdalena Furgalska and Fiona de Londras (2021) Rights, Lawfare and Reproduction: Reflections on the Polish Constitutional Tribunal's Abortion Decision Journal, Israel Law Review (forthcoming).

${ }^{107}$ Vo, 2004 VII Eur. Ct. H.R. at para. 84.

${ }^{108}$ UN. Committee on Economic, Social and Cultural Rights, General comment No. 22 (2016) on the right to sexual and reproductive health (article 12 of the International Covenant on Economic, Social and Cultural Rights) 2.05.2016, E/C.12/ GC/22, http://docstore.ohchr.org/SelfServices/FilesHandler.ashx?enc=4slQ6QSmlBEDzFEovLCuW1a0Szab0oXTdImnsJZZV QfQejF41Tob4CvljeTiAP6sGFQktiaelvlbbOAekmaOwDOWsUe7N8TLm\%2BP3HJPzxjHySkUoHMavD\%2Fpyfcp3Ylzg.

${ }^{109}$ UN Human Rights Committee, Comment, General Comment No. 36 (2018) on Article 6 of the International Covenant on Civil and Political Rights, on the Right to Life, U.N. Doc. CCPR/C/GC/36 (Oct. 30, 2018), https://tbinternet.ohchr.org/Treaties/ CCPR/Shared\%20Documents/1_Global/CCPR_C_GC_36_8785_E.pdf.

${ }^{110}$ Constitution of the Republic of Poland, at art. 41(1).
} 
through the back door, permitting the CT to exercise powers beyond its designated constitutional role, categorized in constitutional literature as those of a "negative legislator."111

As mentioned earlier, the judgment's reasoning demonstrates a rather flexible understanding of the basic interpretative rules and the principles of the constitutional review process. Nevertheless, the situation both leading to and created by the judgment falls short of the standards constituting the rule of law, including "legality, independent and impartial courts, effective judicial review including respect for fundamental rights; and equality before the law". ${ }^{112}$ As such, the judgment complies entirely with the understanding of the role of the constitutional law promoted by the ruling party. It was summarized by one of the Law and Justice MPs in one of the parliamentary debates concerning the Constitutional Tribunal as follows:

Law is something important but it is not sacred .... Above law stands the good of the Nation. If law interferes with this good, we shall not treat law as something inviolable or unchangeable. What I say is this: law shall serve us! Law that does not serve the nation is lawlessness! ${ }^{113}$

A similar sentiment was expressed in the response to the Venice Commission's prepared in 2016 by Parliament-appointed experts, who noted that the principle of democracy-understood as the will of the sovereign, for example, the nation-prevails over the abstract legal order. According to the report, sovereignty cannot be placed in the Constitutional Courts, as it would create "a doctrinal and factual juristocracy," which is contrary to the principle of a democratic state based on the rule of law. ${ }^{114}$ While the law is evidently important, the law remains "an epiphenomenon of the sovereign's will, the will of the nation, and may not be placed above the nation's will in the case of any discrepancy between the two. The law is there and is to be obeyed, but always depending on the nation's approval." 115 As aptly noted by Sadurski, the obsessive invocation of "the figure of the sovereign" allows the ruling party to claim "democratic legitimacy for dismantling the countermajoritarian checks and balances in the system." ${ }^{116}$ Importantly, the judgment constitutes a perfect demonstration of the very particular vision of the Polish nation pursued by the Law and Justice party. In this increasingly radical vision, women are perceived in purely functional and symbolic terms, as reproductive vessels, with very limited control over their bodies and lives; their citizenship and agency acknowledged only as far as it complies with the primary reproductive function.

Commenting on the constitutional crisis in Poland, Bucholc perceptively noted:

The fate of the Tribunal illustrates the double bind between institutions and constitutional order. On the one hand, the Constitution is by definition the basic law and the source of validity criteria in a legal system.... On the other hand, the effect of a constitution depends on institutions complying with the said rules. . . The state of the rule of law ultimately depends on the condition of institutions. ${ }^{117}$

\footnotetext{
${ }^{111}$ Dissenting opinion of judge Leon Kieres and Piotr Pszczółkowski to the judgment K 1/20.

${ }^{112}$ Eur. CoMm'N, supra note 70.

${ }^{113}$ See Mariusz Matczak, Poland: From Paradigm to Pariah? Polish Constitutional Crisis_Facts and Interpretations, THERULEOFLAW.PL (Mar. 8, 2018), https://ruleoflaw.pl/poland-from-paradigm-pariah-polish-constitutional-crisis-facts-andinterpretations/.

${ }^{114}$ Raport Zespolu Ekspertów do Spraw Problematyki Trybunału Konstytucyjnego z dnia 15.07.2016. [The Team of Experts on the Issues of the Constitutional Tribunal of 15 July 2016], SEJM 8 (July 15, 2016), https://www.sejm.gov.pl/media8.nsf/files/ ASEAADRKBW/\$File/Raport\%20Zespo\%C5\%82u\%20Ekspert\%C3\%B3w\%20do\%20spraw\%20Problematyki\%20Trybuna\% C5\%82u\%20Konstytucyjnego.pdf.

${ }^{115}$ BuCHOLC, supra note 74 ,

${ }^{116}$ SADURSKI, supra note 6 , at 8 .

${ }^{117}$ Marta Bucholc, Commemorative Lawmaking: Memory Frames of the Democratic Backsliding in Poland After 2015, 11 Hague J. Rule L. 85, 86 (2019).
} 
It is difficult to argue with this statement. Consequently, it would be very tempting to say that the abortion judgment $\mathrm{K} 1 / 20$ is the result of weak and recently weakened institutions failing to uphold the Constitution, and therefore women's human rights. It would be tempting to see the current judgment as the result of the erosion of democratic principles that have been taken place since the Law and Justice party came to power: The way in which it seized control of the Constitutional Tribunal, certain organs of the Supreme Court, the Public Prosecution's office, the media, and many state-owned companies providing public services. It would be tempting to see the current constitutional crisis, the catastrophic level of "distrust in politicians, parties, institutions, and fellow citizens" as a recent phenomenon associated almost exclusively with the new government actions and practices. ${ }^{118}$ Tempting, but too easy.

The following section of the Article aims to examine the deeper and wider sociological conditions for the development of abortion law and the anti-constitutional backsliding in Poland. It reconfigures the straightforward argument that crises of the rule of law have detrimental effects on reproductive rights. It shows how reproductive rights have for a long time indicated a weak institutionalization of the rule of law and human rights. Bucholc has identified two main reasons why the Polish Constitution and the CT were so weak and therefore so weakly defended. First, in her view, the Constitution lacked "the institutional and cognitive embedding in the legal professions with their education, knowledge, and know-how, and with their internal, group-related frames of memory." 119 Second, before 2015, the Constitution 1997 as a set of norms was "exceedingly jurispathic", for example, its role was to suppress the law made in the course of social practices. ${ }^{120}$ In other words, it promoted a highly positivist and formalistic vision of the law, which suppressed heterogeneous societal meanings, practices, and behavior. The following section demonstrates how the behavior of state institutions - public authorities - contributed to the increasing lack of trust in the law and the Constitution. It shows how lawyers over the years, including those sitting in the CT, co-created the jurispathic character of the Polish Constitution and law. It also shows, how in the case of abortion, it is not only lawyers and legal institutions but also the medical profession, healthcare institutions, and medical organizations that undermined the trust in the legal system. It finally demonstrates how the behavior of these professional groups, especially in the case of abortion, illuminates much more general attitudes to and understandings of the law and the rule of law. As such, it shows why the operationalization of abortion law and reproductive rights, in general, should be seen as an integral part of any assessment of the extent to which democratic principles are entrenched and the rule of law respected.

\section{Long-term Factors: The Operationalization of Abortion Law as a Litmus Test for the Functioning of the Rule of Law}

Writing in 1999, Skąpska claimed that "to be real, the constitutionally proclaimed rule of law must be implemented in the daily life operations of the political system, in the expectations and behavior of functionaries of the system and the attitudes of citizens." ${ }^{21}$ Quoting Perez Diaz, she highlighted the need for consistency between social cognition and institutions, stating, "It is the stage of institutionalization, of the fit between institutional arrangements, popular expectations and behavior, and the legitimation closely linked with it in everyday opinions ... and evaluations which have salient importance for the establishment of liberal, constitutional democracy and civil society." 122 As such, the entrenchment of the rule of law is inherently connected with legal culture, understood as attitudes to law among wide strata of society, in particular

\footnotetext{
${ }^{118}$ SADURSKI, supra note 6 , at 9 .

${ }^{119}$ Bucholc supra note 116 , at 96-97.

${ }^{120} I d$. at 98 .

${ }^{121}$ Grażyna Skąpska, Civic and Legal Cultures in Spain and Poland, 126 Polish Socio. Rev. 223, 225 (1999).

${ }^{122} I d$.
} 
people's understandings of their rights and obligations and their expectations towards the judiciary and legal institutions more generally, and their fellow citizens. ${ }^{123}$ Seen from this perspective, the functioning of the rule of law should be assessed not only through analysis of the visible-even ostentatious - political and legal acts, some of which may be directed at seizing control over legal institutions. It is far more important to investigate the far less visible everyday experiences of legality and extra-legality, the spaces where social practices take little notice of or consciously circumvent the law. It is crucial to analyze "how individuals, groups, networks react or do not react to formal law, which does not reach them or is considered unimportant, because there are no official reactions to circumventing the law." 124

A brief discussion of the recent history of reproductive rights in Poland helps explain why the analysis of their development and operationalization is vital to assessing the aspects mentioned above of the rule of law. While under the Socialist regime, abortion was legal and widely available for almost 40 years, ${ }^{125}$ the political and socio-economic transition, formally initiated in 1989 , gave rise to one of the most restrictive abortion regimes in Europe. ${ }^{126}$ Since the late 1980s, Polish society has experienced the systematic introduction of restrains on access to reproductive rights. This retrenchment is commonly attributed to the hegemonic position of religious organizations, traditional social structures, and complex political dynamics after $1989 .{ }^{127}$ It also reveals the persistent and increasing disjunction between law, institutions, and social cognition. This disjunction stems from the normalization of illegality, legal uncertainty, and distrust towards public authorities and institutions. This, in turn, can undermine general confidence in legal principles and procedures; it can also undermine confidence in medical organizations and healthcare professionals. As a result, public regard for institutions that are fundamental to functioning democracies is likely to be diminished. Consequently, the following section further demonstrates the significance of professional groups as structural elements of the rule of law. While the role of lawyers is often noted in such discussions, the acknowledgment of healthcare professionals as actors shaping the development and institutionalization of the rule of law is far less common.

\section{The Medical Profession and the Rule of Law}

The Polish medical profession carries substantial responsibility for developing a restrictive abortion regime and the protracted and weak entrenchment of the rule of law in Poland after 1989. First, as soon as the Polish Chamber of Physicians was reinstated in 1989, it actively supported further criminalization of abortion. ${ }^{128}$ The first General Assembly of Physicians—which is part of

\footnotetext{
${ }^{123}$ Jacek Kurczewski, Prawem i Lewem. Kultura Prawna Społeczeństwa Polskiego po Komunizmie [Right and Left. Legal Culture of Polish Society After Communism], 2 STUdia SocjologiczNe 33, 34 (2007).

${ }^{124}$ Adam Czarnota \& Martin Krygier, Po komunizmie-Następny Etap? [After Communism-The next stage?], 2 STUDIA SoCJOLOGICZNE 145, 161 (2006) (emphasis added).

${ }^{125}$ Approximately 150,000 abortions were registered a year. See Eleonora Zielińska, Between Ideology, Politics, and Common Sense: The Discourse of Reproductive Rights in Poland, in: Reproducing Gender: Politics, Publics and Everyday Life AFTER SOCIALISM (Susan Gal \& Gail Kligman eds., 2000).

${ }^{126}$ Małgorzata Fuszara, Legal Regulation of Abortion in Poland, 17 SIGNS 117 (1991); Hanna Jankowska, Abortion, Church and Politics in Poland, 39 Feminist Rev. 174 (1991); Joan Hoff, Comparative Analysis of Abortion in Ireland, Poland, and the United States, 17 Women's Stud. InT'L F. 621 (1994); Andrzej Kulczycki, Abortion Policy in Postcommunist Europe: The Conflict in Poland, 21 Population \& Dev. Rev. 471 (1995); Agnieszka Graff, Ricochet: On Gender, Sexuality, and Nation (2008); Joanna Mishtal, The Politics of Morality: The Church, the State and Reproductive Rights in Post-SOCIALIST POLAND (2015).

${ }^{127}$ Anna Titkow, Poland, in From Abortion to Contraception: A Resource to Public Policies and Reproductive Behavior in Central and Eastern Europe from 1917 to the Present, (Henry P. David ed., 1999); Cinderella Goes to Market: Citizenship, Gender and Women’s Movements in East Central Europe (Barbara Einhorn ed., 1993); Graff, supra note 124; Malgorzata Fidelis, Women, Communism, And Industrialization in Postwar Poland (2010).

${ }^{128}$ See Irmina Kotiuk, Kalendarium-100 Lat Historii Walki o Prawo do Aborcji w Polsce [Calendar-100 years of History of the Fight for the Right to Abortion in Poland], ARCHIwUM OsIATYNSKEIGo (June 7, 2018), https://archiwumosiatynskiego. $\mathrm{pl}$ /wpis-w-debacie/kalendarium-100-lat-historii-walki-o-prawo-do-aborcji-w-polsce/.
} 
the Chamber-adopted a resolution calling the Polish Parliament to change the Abortion Act 1956, committing the Chamber to participate in preparing the new Bill on the protection of the "conceived life." 129 The second General Congress adopted the first Medical Code of Ethics in 1991, which contained a provision that allowed doctors to perform abortions, "risk the fetus" life, only in cases where it was necessary to save the life and health of the mother, ... where the pregnancy resulted from a criminal act," and prohibited abortion if the fetus was diagnosed with a developmental or genetic disorder. ${ }^{130}$ As such, the document promoted a legislative solution that we are experiencing in Poland today due to the recent judgment $\mathrm{K} 1 / 20$. The provisions of the Medical Code 1991 were in clear contravention of the Act on the Conditions of Lawful Pregnancy Termination (1956) (Abortion Act 1956), ${ }^{131}$ which decriminalized abortion for women and introduced socio-economic factors as a ground for lawful termination of pregnancy and was still in force at the time. Although the relevant provisions of the Medical Code of Ethics 1991 were amended following a series of constitutional challenges initiated by the newly appointed Commissioner for Human Rights, Ewa Łętowska, in 1992, ${ }^{132}$ the Chambers continued to pursue a strong pronatalist agenda and lobby in favor of the re-criminalization of abortion. In doing so, they disregarded the limitations set by legal and constitutional provisions. Some members of the medical profession argued strongly against such changes. However, most of them remained silent and withdrawn. As a result, the current 1993 Act was adopted in 1993. ${ }^{133}$ The Polish Chamber of Physicians became less ostensibly politically active after the adoption of the Act 1993. However, the medical profession retained the decision-making power in the area of reproductive rights. Importantly, despite the absence and invisibility of doctors in abortion debates, the Chamber was behind the CT (K 12/14) judgment issued in 2015, which considerably widened the scope of conscientious objection amongst medical professionals. ${ }^{134}$ The litigation was presented as a general struggle for wider clinical autonomy and decision-making power by individual doctors. However, in reality, it provided strong support for healthcare institutions wanting to restrict access to abortion and to justify their refusal to provide lawful abortion services. It also revealed the extent to which professional bodies can shape the regulatory abortion framework and influence institutional and individual practice. ${ }^{135}$

In principle, the legal activism of professional groups is itself common and should be promoted as a means of negotiating vital interests of important societal constituencies. Yet, the involvement of the members of the Chamber behind the scenes of the legislative processes in the early 1990s reflects the authority of the medical profession in Polish society, and raises serious questions about the constitutional position and power of medical organizations. An interview given by Ewa

\footnotetext{
${ }^{129}$ Krajowy Zjazd Lekarzy Naczelnej Izby Lekarskiej [National General Meeting of the Polish Chamber of Physicians], Resolution, KZL NIL (Dec. 12, 1989).

${ }^{130}$ Kodeks EtYKi LeKarskiej (Code of Medical Ethics), Dec. 14, 1991, https://sip.lex.pl/akty-prawne/akty-korporacyjne/ kodeks-etyki-lekarskiej-286454095.

${ }^{131}$ Dz. U. 1956.12 .61 (Pol.).

${ }^{132}$ [Resolution of Constitutional Court] U 1/92 Państwo i Prawo 1992/12, 99 (Pol.); [Judgment] W 16/92 [Constitutional Tribunal] OTK 1993/I poz. 16, 156 (Pol.).

${ }^{133}$ At the moment, there is a two-year delay in the Government Reports on the implementation of the Act on Family Planning, the Protection of the Human Fetus, and Conditions Permitting Pregnancy Termination 1993. The Government Report published in 2019 covers data concerning 2017. See Sprawozdania Rady Ministrów z wykonywania w latach 19932017 oraz o skutkach stosowania ustawy $z$ dnia 7 stycznia 1993 r. o planowaniu rodziny, ochronie plodu ludzkiego $i$ warunkach przerywania ciazy [Reports of the Council of Ministers on the performance in the years 1993-2017 and on the effects of the application of the Act of 7 January 1993 on family planning, protection of the human fetus and conditions for termination of pregnancy], Dz. U. poz. 78, z późn. zm., (1996-2019).

${ }^{134} \mathrm{~K} 12 / 14$ OTK ZU 9A/15 poz. 143 (Pol.).

${ }^{135}$ Atina Krajewska, Rupture and Continuity: Abortion, the Medical Profession, and the Transitional State-A Polish Case Study, FEMINIST LEGAL STUD. (forthcoming 2021), https://link.springer.com/article/10.1007\%2Fs10691-021-09465-3.
} 
Łętowska in 2012 provides a perfect illustration of the connections between medical and state authorities and the attitudes to law and legal institutions displayed by the medical profession. Reminiscing about her time as the Polish Commissioner for Human Rights in the early 1990s, Łętowska recalled an informal visit from a doctor and a prominent member of the Chamber of Physicians who aimed to secure her support for the restrictive amendments of abortion law. ${ }^{136}$ The physician mentioned in the interview was Professor Bogdan Chazan, one of the most prominent voices in the anti-choice movement, who later became the National Gynecology and Obstetrics Consultant. Such attempts to exert informal pressure on persons in public office demonstrate not only the nature of legal institutions at the early stages of democratization in Poland but also the weak institutionalization of the rule of law understood as a system that assumes separation of different loci of political, legal, and professional power.

Second, and more importantly, over the years, the medical profession has erected unnecessary medical and procedural barriers that prevent women from accessing lawful abortion services, mainly in public hospitals. In so doing they have gone beyond what is required by abortion law and have persistently violated legal principles stipulated in the Act 1993, the Act on the Professions of Physician and Dentist 1996, ${ }^{137}$ the Constitution 1997, and human rights treaties. These violations have been reported by many different international human rights bodies ${ }^{138}$ and led to many cases before the European Court of Human Rights (ECtHR). In Tysiac gynecologists refused access to lawful abortion to a woman despite the fact that three ophthalmologists concluded that carrying the pregnancy to term constituted a serious risk to her eyesight, a risk which later materialized qualifying the applicant as a person with a serious disability in the Polish welfare system. ${ }^{139}$ The ECtHR found that the lack of appropriate procedures to review the doctors' decision violated the applicant's right to privacy guaranteed in Article 8 ECHR. In $R R$, doctors, hospitals, and administrators repeatedly denied a pregnant woman access to prenatal genetic examination, diagnostic tests, and medical information about her pregnancy until abortion was no longer an option. ${ }^{140}$ This was done despite the fact that fetal irregularities were discovered during a sonogram early in pregnancy and that the Polish law at the time permitted termination of pregnancy in such cases. In a landmark decision, the ECtHR found for the first time that the behavior of public authorities amounted to inhumane and degrading treatment and therefore violated Article 3 ECHR. Finally, in $P$. and $S$., a minor was denied access to abortion, although the pregnancy was a result of rape, a case stipulated in the Act 1993 as a ground for lawful abortion. ${ }^{141}$ The applicant and her mother encountered multiple obstacles, including doctors' refusal to perform a legal abortion, lack of referral to a different provider, provision of false or distorted information about the legal requirements to access abortion care, and disclosure of personal and medical information to the press, which resulted in harassment of the applicants by doctors, members of the clergy, and anti-abortion groups. In addition, the minor was removed from her mother's custody and detained for a short period of time in a juvenile center. Unsurprisingly, the treatment of both applicants by healthcare professionals and public authorities was found to violate Article 3 and Article 8 of the ECHR. These cases constitute just a few examples of a much wider phenomenon deeply rooted in professional and legal culture. Personal histories of women

\footnotetext{
${ }^{136}$ Ewa Łętowska \& Krzysztof Sobczak, Rzeźbienie Państwa Prawa. 20 Lat Później [Krzysztof Sobczak, Sculpting the Rule of Law. 20 years later], 95 (2012).

${ }^{137}$ Dz. U. 2020.514, 567 (Pol.).

${ }^{138}$ U.N. Human Rights Committee, Concluding observations on the seventh periodic report of Poland, U.N. Doc. CCPR/C/ POL/7 (2016); U.N. Doc. CCPR/C/SR. 3306; U.N. Doc. CCPR/C/SR. 3308.

${ }^{139}$ Tysiac v. Poland, (No. 5410/03) 2007 IV Eur. Ct. H.R, http://hudoc.echr.coe.int/eng?i=001-79812.

${ }^{140}$ R.R. v Poland (No. 27617/04) 2011 IV Eur. Ct. H.R., http://hudoc.echr.coe.int/fre?i=001-104911.

${ }^{141}$ P. and S. v. Poland (No. 57375/08) 2013 IV Eur. Ct. H.R., http://hudoc.echr.coe.int/fre?i=001-114098.
} 
who experienced abortion care in Poland collected by the Federation for Women and Family Planning paint a grim picture of discrimination and structural violence. ${ }^{142}$

The way that the medical profession behaves in the context of abortion both indicates and influences the function of the rule of law. Persistent violations of women's human rights do not happen in a vacuum. They indicate weak institutionalization of the rule of law because they mean that corrective legal or professional mechanisms of such behavior are weak or do not exist. With the exception of the office of the Commissioner for Human Rights, and to a lesser extent, the Commissioner for Patients' Rights, public authorities and medical organizations are either absent or ineffective or both in enforcing the existing law and professional standards. For instance, when Alicja Tysiąc, the applicant in one of the cases before the ECtHR, attempted to bring professional proceedings against the doctors who refused to perform the lawful abortion, the competent authorities of the Chamber of Physicians found no case of professional negligence and the proceedings were discontinued. Similarly, district and regional public prosecution services found no causal link between the refusal of the doctor to perform an abortion and the deterioration of the woman's eyesight. The ECtHR subsequently established that the offices of the public prosecution services dealing with the case dismissed it without proper examination and hindered the applicant's ability to exercise her procedural rights during the investigations. ${ }^{143}$ This was not an isolated case. For years, members of professional groups and organizations, as well as law enforcement agencies, have been persistently failing to protect the rights, health, and life of their citizens. Civil and criminal courts have not provided sufficient protection against these abuses of power. In the few cases that reached the courts and damages were awarded, they were low and inevitably awarded after the harm was done. ${ }^{144}$ It is difficult to imagine that these habitual forms of behavior would not undermine societal confidence in legal principles and procedures, and in turn, lead to a more general loss of trust in public institutions. Such patterns of behavior can do nothing but undermine the faith of a significant number of citizens in their system of government. It is difficult to talk about the rule of law where the laws do not "inform people what to expect of others." 145

Finally, there is the metaphorical elephant in the room: Restrictive abortion regimes almost invariably stimulate illegal medical practices, giving rise to the phenomenon known as the "abortion underground." It is commonly accepted that the estimated number of illegal abortions in Poland, although impossible to assess precisely, has oscillated between 80,000 and 150,000 a year since the 1993 legal reforms. ${ }^{146}$ This means that for decades, Polish citizens have experienced a disjunction between institutional—official—and individual — covert—behavior concerning the provision of abortion services. Furthermore, they experience a legal system that continues to promote inequality, as access to abortion remains "open" to those with financial means. An opinion poll conducted in 2013 found that at least one in four Polish women had an abortion at least once in their lives, which translated into a number between 4.1 and 5.8 million women. The scale of the phenomenon demonstrates that the experience of extra-legality or illegality is very common, as it affects not only the women having abortions but also people close to them. The scale of the phenomenon further suggests that, over the years, public authorities were only symbolically interested

\footnotetext{
${ }^{142}$ See \#Historiekobiet, FeD’N WOMEN \& PLANNING (Sept 25. 2018), https://federa.org.pl/historiekobiet/.

${ }^{143}$ Tysiąc v. Poland, App. No. 5410/03.

${ }^{144}$ Wyrok SN z 13.10.2005 r. (IV CK 161/05), OSP 2006/6/71; Uchwała SN z 22.02.2006 r. (III CZP 8/06), OSNC 2006/ 7-8/123. 15 Wyrok SN z 12.06.2008 r. (III CSK 16/08), OSNC 2009/3/48. 16 Wyrok SN z 6.05.2010 r. (II CSK 580/09), LEX nr 602234. 17 Wyrok SA w Krakowie z 12.05.2015 r. (I ACA 204/15), LEX nr 1755143.

${ }^{145}$ Barry Weingast, A Postscript to Political Foundations of Democracy and the Rule of Law, in DEMOCRACY AND THE RULE OF LAW 109 (Jose Maria Maravall \& Adam Przeworski eds., 2009).

${ }^{146}$ Françoise Girard \& Wanda Nowicka, Clear and Compelling Evidence: The Polish Tribunal on Abortion Rights, 10 Reprod. Health Matters 22 (2002); Annual Report 2013, Fed’N Women \&Family Planning (2013), https://federa. org.pl/1242-2/raport_federacja_2013/.
} 
in enforcing the law. There have been very few cases in which healthcare professionals providing abortion services outside the framework of the Act 1993 were prosecuted or convicted for providing abortion to a woman with her consent. At the same time, ample anecdotal evidence suggests that law enforcement agencies often target and harass women seeking an abortion, despite the fact that, as mentioned earlier, they do not commit an offense according to Polish criminal law. While this lenience of enforcement agencies and courts towards the medical profession allows for at least some access to abortion services, their selective and targeted behavior also contributes to legal uncertainty, ambiguity, and thus, in turn, further undermines trust in state institutions and the law.

\section{Constitutional Judges in Battles over Reproductive Rights}

As mentioned earlier, the behavior of the medical profession does not occur in a vacuum. The attitudes towards and broader understandings of the law and its functions in society depend on the everyday experiences of the legal system and the way in which it resolves legal conflicts and tensions. These, to a large extent, are shaped by the legal profession, especially the judiciary. Since 2015 we have seen large and unprecedented popular mobilization in defense of the courts. ${ }^{147}$ At the same time, it has been noted that one of the reasons why the government managed to obtain control over the judiciary was due to the low regard for the judiciary among the public. While opinion polls conducted among EU citizens showed that Poles do not diverge in their opinion of the courts from other European societies, in 2017, fifty percent of the respondents of a national survey still reported bad or very bad experiences with the judiciary, and over fifty percent negatively assessed the quality of the Polish judiciary. ${ }^{148}$ Some commentators have rightly suggested that this relatively high dissatisfaction was the result of a negative media campaign employed by the government. ${ }^{149}$ Yet, it is worth mentioning that the views had not changed substantially in comparison with previous years. In 2012, three years before the Law and Justice party came into power, forty-eight percent of respondents reported bad or very bad experiences in courts, but over sixty percent had a negative view of the judiciary. ${ }^{150}$ Most of these views relate to procedural aspects of the access to justice, lengths and costs of the proceedings, or perceptions of corruption among the judges and lawyers more generally. Little is usually said about substantive justice and equality. Here, analysis of reproductive rights reveals high levels of politicization of the Polish judiciary even pre-2015. In particular, since the early 1990s, the CT consistently supported creating a restrictive abortion regime. While it is often claimed the general population hardly noticed the pronouncements of this judicial body, they have had severe and very tangible consequences for persons wishing to make reproductive choices.

In the early 1990s, when the Polish Commissioner for Human Rights challenged the attempts to widen the power of physicians to deny access to abortion, still lawful under the Act 1956, the CT either supported such attempts or avoided taking a stand with regard to substantive rights. ${ }^{151}$ In one of the first judgments concerning abortion, (U 8/90), the Tribunal inferred from a general clause on the freedom of consciousness guaranteed by the amended Constitution 1952, the right to refuse the provision of abortion services, unless the abortion is necessary to save the life of the woman. As early as 1991, Zielińska noted critically that the reasoning employed by the Tribunal undermined the principle of the rule of law. One of the reasons for the criticism was that the legal

\footnotetext{
${ }^{147}$ Bucholc speaks of the "jurisgenerative potential" released by the recent attacks on the judiciary. See Bucholc, supra note 116 , at 98

${ }^{148}$ Raport Centrum Badań Opinii Społecznej: Społeczne Oceny Wymiaru Sprawiedliwości (Report of the Public Opinion Research Center: Social Evaluation of the Judiciary), No. 31, CBOS (2017), http://www.cbos.pl/SPISKOM.POL/2017/K_ 031_17.PDF.

${ }^{149}$ SADURSKI, supra note 6 , at 98.

${ }^{150}$ Raport Centrum Badań Opinii Społecznej, supra note, 146.

${ }^{151}$ TK U 8/90, OTK 1991.8 (Pol.); TK U 1/92 OTK 1992.38 (Pol.).
} 
system at the time, including the Constitution, still allowed for the provision of abortion services and stipulated a narrower scope of possible conscientious objection of the medical professional to perform medical procedures. ${ }^{152}$ In the case challenging the introduction of the Medical Code of Ethics 1991 (U 1/92), the provisions of which were contrary to the Abortion Act 1956, the CT held that because the provisions of the Code constitute deontological standards, they cannot be subject to constitutional review. As such, the CT avoided taking a stand on the substance of the introduced provisions limiting access to abortion. ${ }^{153}$ One could argue that the Tribunal acted correctly, upholding the separation of powers. However, such interpretation fails in light of the fact that the majority judgment was called into question by a series of dissenting opinions. In these opinions, four judges claimed that the Code was drafted and adopted by the Chamber of Physicians, operating as a body of professional self-governance; for example, a public law entity performing administrative functions public on a statutory basis allows for its constitutional review. ${ }^{154}$ While dissenting opinions can be seen as reflection and evidence of the well-functioning judicial processes, the majority judgment indicates that, despite the systemic change in 1989, the politicization of the CT continued. Because the Tribunal signaled a lack of coherency between the ethical and legal standards, the Parliament rushed through the adoption of the Act 1993 severely restricting access to abortion services in Poland.

The CT issued two more important judgments before the Law and Justice party came to power at the end of 2015. These judgments opened up the possibility of restrictive interpretation of abortion law and shaped the scope of abortion care in Poland in the last decades. In 1997 the CT held unconstitutional an amendment to the Act 1993 permitting abortions on socio-economic grounds, briefly introduced by the Social Democratic government in $1996 .{ }^{155}$ Paradoxically, the Tribunal inferred the protection of life from the moment of conception from the general rule of the rule of law, enshrined in the "Small Constitution" of 1992. The Tribunal noted that "in a state under the democratic rule of law," human life is the utmost value that must be constitutionally protected at every stage of its development. According to the Tribunal, this protection included the prenatal stages of human life and could not "be subject to any differentiation."156 The Tribunal reasoned that "[f]rom the essence of recognizing human life as a constitutional value, there results the need to limit the rights of the pregnant woman." While formally in the name of the rule of law, the judgment (K 26/96) contributed to the development of one of the most restrictive abortion regimes in Europe that disregarded the rights and freedoms of pregnant persons and their families. The judgment played a crucial role in reinforcing the rhetoric of the so-called "abortion compromise" in public debates. The latter began to be viewed as the only possible regulatory response to questions concerning reproductive rights and other contested social problems. But the Tribunal did not stop there. In October 2015-weeks before the Law and Justice party came to power-the CT employed once again a wide interpretation of some constitutional principles and issued a judgment (K 12/14), which eventually widened the scope of the health care professional's right to raise a conscientious objection. ${ }^{157}$ The Tribunal held that the right to conscientious objection-inferred from the freedom of consciousness guaranteed in the Constitution 1997—should be seen as a primary right and, therefore, prioritizing any provisions that limit its

\footnotetext{
${ }^{152}$ Eleonora Zielińska, Glosa do Orzeczenia TK z Dnia 15 Stycznia 1991 r. U 8/90 [Glossary to the Judgment of the Constitutional Tribunal of 15 January 1991, U 8/90], 7 PAŃSTwO I PRAwO 112 (1991).

${ }^{153}$ Anna Korytowska, Problem Zgodności Kodeksu Etyki Lekarskiej z Konstytucja RP [The Problem of Compliance of the Code of Medical Ethics with the Polish Constitution], LXX1 RuCH Prawniczy, EKONOMICZNY, I SocJOlOGICZNY 53 (2009).

${ }^{154} \mathrm{U}$ 1/92, OTK 1992, nr 2, poz. 38 (Pol.).

${ }^{155}$ K 26/96 OTK 1997/2/19 (Pol.).

${ }^{156} \mathrm{Id}$.

${ }^{157}$ OTK-A 2015/9/143 (Pol.).
} 
essence. It followed that the right to refuse to provide abortion services based on conscience could only be limited if the life of the woman is in danger. From that point on, individual doctors have not been obliged to direct women to other physicians ready to provide abortion care. As such, the judgment was criticized by the Commissioner for Human Rights and civil society organizations. ${ }^{158}$ It could be argued that these judgments do not undermine the rule of law as such. On the contrary, they reflect normal functioning's of the multi-centric - and, more importantly, a democraticlegal system based on checks and balances. Yet, such claims are based on the assumption that the judiciary remains independent. This can hardly be said about the judges of the Polish Tribunal. For instance, nine months before the judgment concerning conscientious objection was issued, the President of the CT, Andrzej Rzepliński, was awarded the papal cross Pro Ecclesia et Pontifice for his services to the Church and the legal system in Poland. ${ }^{159}$ The fact that the same person has since become the symbol of the judicial resistance to the changes introduced by the Law and Justice party does not invalidate the questions concerning the functioning of the rule of law in Poland before 2015. While the CT judges are not representative of the entire legal profession, their actions give some indication of the general legal culture. The example of the President of the CT certainly demonstrates-once again-how reproductive rights have the power to reveal fissures in the function of a legal system based on the rule of law.

\section{E. Conclusions}

This Article aimed to highlight the close relationship between reproductive rights, the rule of law, and democracy. It argued that this relationship came into full light in the context of the COVID-19 pandemic. The pandemic created a unique opportunity for governments to pursue their long-term agendas, and as such, it intensified existing ideological and policy patterns and trends. In the case of Poland, the Article showed how the Polish government utilized the outbreak of COVID-19 and its newly created "emergency powers" to introduce a controversial change in abortion law and the extent to which it was prepared to go to constrain social unrests that followed the announcement of the judgment by the CT. However, the Article argued that the events and legal developments in times of COVID-19 constitute the metaphorical "tip of the iceberg." Both the contents of the abortion judgment and the legal context in which it was issued can be seen as a perfect exemplification of the "populist anti-constitutional backsliding" that could be witnessed in Poland in recent years. However, while many legal scholars and commentators tend to associate the current constitutional and democratic crisis with the rise of the Law and Justice party as a dominant political force, this Article challenges such claims. It argues that analysis of the way in which reproductive rights developed and operated in Poland in recent decades reveals weak institutionalization of the rule of law and legal institutions. In Poland, the criminalization of abortion encouraged a disregard for law and legal principles, thus undermining the basis of society based on the rule of law. Both legal and medical professions played an important role in such development and should be seen as critical structural elements of a constitutional democracy based on the rule of law. Consequently, the Article has elucidated why reproductive rights should be incorporated into assessments of the institutionalization and entrenchment of the rule of law in

\footnotetext{
${ }^{158}$ Rzecznik Praw Obywatelskich, Do MZ ws. wykonania wyroku Trybunału Konstytucyjnego dotyczacego klauzuli sumienia [To the Ministry of Health on the implementation of the judgment of the Constitutional Tribunal regarding the conscience clause], RPO (Dec. 14, 2015), https://www.rpo.gov.pl/pl/content/do-mz-ws-wykonania-wyroku-trybunalu-konstytucyjnegodotyczacego-klauzuli-sumienia.

${ }^{159}$ Ewa Siedlecka, Prof. Andrzej Rzepliński Odznaczony za Zasługi dla Kościoła. Prawnicy w Szoku [Prof. Andrzej Rzepliński Decorated for his Services to the Church. Lawyers in shock], GAZETA WybORCZA (Jan 25, 2015), https://wyborcza.pl/ 1,75398,17307048,Prof_Andrzej_Rzeplinski_odznaczony_za_zaslugi_dla.html?disableRedirects=true.
} 
transitional societies. The Article has argued that reproductive rights, defined in broad terms, should be seen as important parts of the "litmus test," which we use to examine the efficacy of democratic transitions and the quality of the democracies in which such transitions result. Adequate protection of reproductive rights cannot be viewed as a marginal aspect of democracy, and such rights are an essential element of the legal fabric of a democratic society. 